\title{
Mümkün Âlemlerin En Mükemmeli ve Semhûdî'nin Gazzâlî Savunması*
}

\section{The Best of All Possible Worlds and Samhûdî's Defense of Ghazzālî}

\author{
Azer ABDURRAHMAN \\ Doktora Öğrencisi, Marmara Üniversitesi, Sosyal Bilimler Enstitüsü, Temel İslam Bilimler \\ Anabilim Dalı, Kelâm Bilim Dalı \\ Ph.D. Student, Marmara University, Institute of Social Sciences, Department of Basic \\ Islamic Sciences, The Discipline of Kalam \\ Istanbul, Turkey \\ azerabdurrahman@gmail.com \\ orcid.org/0000-0003-0336-6094
}

\author{
Makale Bilgisi / Article Information \\ Makale Türü / Article Types \\ Geliş Tarihi / Received \\ : Araştırma Makalesi / Research Article \\ Kabul Tarihi / Accepted \\ : 15 Ekim / October 2019 \\ Yayın Tarihi / Published \\ : 18 Kasım / November 2019 \\ Yayın Sezonu / Pub Date Season : Aralık / December \\ Cilt / Volume: 6 - Sayı / Issue: 2 - Sayfa / Pages: 307-332 \\ Atıf / Cite as \\ Abdurrahman, Azer. "Mümkün Âlemlerin En Mükemmeli ve Semhûdî'nin Gazzâlî Savunması". Bülent Ecevit \\ Üniversitesi Illahiyat Fakültesi Dergisi, 6/2 (2019): 307-332 \\ Doi: 10.33460/beuifd.633503 \\ Intihal / Plagiarism \\ Bu makale, en az iki hakem tarafından incelendi ve intihal olmadığı teyit edildi. \\ This article has been reviewed by at least two referees and scanned via a plagiarism software. \\ Yayın Hakkı / Copyright ${ }^{\circ}$ \\ Zonguldak Bülent Ecevit Üniversitesi, İlahiyat Fakültesi tarafından yayınlanmıştır. Tüm hakları saklıdır. \\ Published by Zonguldak Bulent Ecevit University, Faculty of Theology, Zonguldak, Turkey. All rights reserved.
}

Öz: Gazzâlî́nin, "mevcut evrenden daha mükemmelini yaratmak imkân dâhilinde değildir" şeklinde ifade ettiği âlemin mükemmelliği ile ilgili düşüncesi, kendisi henüz hayattayken büyük tartışmaların ortaya çıkmasına sebep olmuştur. Gazzâlîile bu konuda aynı görüşleri paylaşan Semhûdî de onu takip ederek, içerisinde belli bir amaca yönelik kötülükler ve iyilikleri aynı anda barındıran bu âlemin, mümkün âlemler içerisinden seçilen en mükemmel âlem olduğu görüşünü savunmaktadır. Ona göre âlemin en mükemmel şekilde yaratılması, Allah'ın hür seçiminin ve mutlak iradesinin bir sonucu olarak ve hikmetinin gerektirdiği en mükemmel oluş şeklinde tezahür eder. Allah'ın hikmeti iradesi ve kudretinin sınırsız olanı sınırlı yapabileceğini söyleyen Semhûdî, Allah için her zaman daha mükemmelini yaratmanın imkân dahilinde olmasına rağmen bir

\footnotetext{
* Bu makale, yazarın Marmara Üniversitesi Sosyal Bilimler Enstitüsü Temel İslam Bilimleri Anabilim Dalı Kelam Bilim Dalı́nda savunma aşamasında olan doktora tezinden yararlanılarak hazırlanmıştır.
} 
fert için en mükemmellik vasfının seçilmesi, seçilenin o an için en mükemmel olduğu ve onun Allah tarafından sınırlandırıldığı anlamına geldiğini savunur. Aynı zamanda âlemin, aklın algıladığı itibarî kavram olan en mükemmellik ile vasıflanması, onun bu özelliğinin tüm zamanlar için sabit kalarak değişmez olduğu anlamına gelmemekte, mükemmel olarak var olan her şey, ilâhî hikmet böyle gerektirdiği için kendi zamanına göre en harika olarak yaratılmaktadır. Sonuç olarak içinde bulunduğumuz âlemin imkân dahilinde en mükemmel olması tartışılmaz bir gerçektir.

Bu çalışmanın ana hedefi, Gazzâlî'nin, tartışmalara vesile olan âlemin mükemmelliğine dair temel düşüncesi üzerine Ibnü'l-Müneyyir'in ileri sürdüğü eleştirileri ve bu eleştirilere Semhûdînin verdiği cevapları ana hatlarıyla ortaya koymaktır.

Anahtar Kelimeler: Kelâm, Gazzâlî, Ibnü'l-Müneyyir, Semhûdî, teodise-kötülük problemi, mümkün âlemlerin en mükemmeli, hikmet, adâlet

\begin{abstract}
Ghazzäli's thought about the perfection of the world which we can express it as "it is impossible to create more perfect than the current world", caused great disputes while he was still alive. Samhûdi, who shared the same views with Ghazzäli on this subject, following him, defends the thesis that the existing world which contains good and evil for a certain purpose at the same time is the best of all possible. According to him, the most perfect creation of the world is the result of God's wisdom, free choice and absolute will. Samhudi, who said that God's will, power and the divine wisdom is capable of making the limited unlimited, also defends the view that God's choice of excellence for an individual means that it is perfect for that very moment and it is restricted by God, although it is always possible for God to create more perfect. At the same time, describing the world with the perceptual most excellent concept does not necessarily mean that it is invariable for all times and everything that exists perfectly is created to be the greatest in its own time, as divine wisdom requires it. As a result, it is an indisputable fact that the world we are in is the best of all possible.
\end{abstract}

Main purpose in this article is to outline the criticisms of Ibn al-Munayyir on Ghazzäli's controversial thought about the perfection of the world and Samhûdî's defense against these criticisms.

Key words: Kalam, Ghazzāli, Ibn al-Munayyir, Samhudi, theodicy, best of all possible worlds, divine wisdom, divine justice, divine will

\title{
Giriş
}

Alemde var olan kötülük olgusuyla, zulüm yapmayan, kötü olmayan, en mükemmel şekilde yaratan, âdil, kudretli ve hikmet sahibi olan Allah'ın varlığının çelişkili olduğu düşüncesi, insanlık tarihinde başlangıçtan beri tartışılan en önemli konulardan biri olmuştur. Bu sebepledir ki, kötülük olgusu ve doğurduğu sorunlara dair tartışmalar günümüze kadar süregelmiş ve popülerliğini kaybetmemiştir. 
Alemin mükemmelliği düşüncesi de bu problemin çatısı altında tartışılan en önemli konulardan biridir. Yaşadığımız bu dünya gerçekten en mükemmel şekilde mi yaratılmıştır, yoksa Allah bundan daha mükemmelini yaratabilir miydi? Eğer bu alem var olan alemlerin en mükemmeliyse o zaman neden insanlık kötülüklerle karşı karşıya bırakılmıştır? Allah hiçbir kötülüğün bulunmadığı, her kesin mutlu olarak yaşayabileceği bir dünya yaratmaktan âciz midir? Eğer buna kudreti yetiyorsa neden böyle bir dünya yaratılmadı? İnsanlık, zihnini meşgul eden bu tarz soruları düşünmekten kendini alıkoyamamış ve problemi çözmek adına çeşitli teoriler geliştirmiştir.

İslam kelamında Mûtezile ile birlikte başlayan kötülük ve dünyanın en mükemmel şekilde yaratılması konusu ile ilgili tartışmalar, Gazzâlî'nin konuyu birkaç eserinde ${ }^{1}$ o zamana kadar pek de alışılagelmeyen bir üslupta ifade etmesiyle alevlenmiş ve kendisinden sonra uzun bir dönem gündemden düşmemiştir.

Temelinde, eski Yunan felsefi düşüncesinin esintilerini barındıran², "mevcut evrenden daha mükemmelini yaratmak imkân dâhilinde değildir (leyse fi'l-imkân

1 Gazzâlî, Makāsidü'l-felâsife, Ihyấu 'ulûmi'd-dîn, el-Maksadü'l-esnâ fî şerhi esmâillahi'l-hüsnâ, Cevâhiru'l-Kur'ân'ın bir bölümü olan Kitâbu'l-Erbaîn ve el-Imlấ' fî işkâlâti'I-Ihyâ isimli beş eserinde bu konu ile ilgili fikir beyan etmektedir. Bk. Ebû Hâmid Gazzâlî, Makāsidü'l-felâsife, trc. Cemaleddin Erdemci (Ankara: Vadi Yayınları, 2001), 186, 230-233; îhyâ'u 'ulûmi'd-dîn (Kahire: Mustafa el-Bâbî el-Halebî, 1939), 4: 252-253; el-Maksadü'l-esnâ fî şerhi esmâillahi'I-hüsnâ (Beyrut: Dârü'l-Kütübi'l-IImiyye, ts.), 43-44; Cevâhiru'I-Kur'ân ve düreruhu, thk. Hatice Muhammed Kâmil (Kahire: Darü'l-Kütüb ve'l-Vesaiki'l-Kavmiyye, 2011), 66; Kitâbu'l-Erbaîn fî usûli'd-dîn (Kahire: Matbaatu Kürdistani'I-IImiyye, 1328), 275-277, 280-283, 307-312; el-Imlâ fî işkâlâti'l-Ihyâ (Ihyâ'nın zeylinde), 4. Baskı (Beyrut: Dârü'l-Hayr, 1997), 6: 235-236. Ayrıca eserlerin yazııma sırası ile ilgili bk. Abdurrahman Bedevî, Muellefâtü'lGazzâlî, 2. Baskı (Kuveyt: Vekaletü'l-Matbuat, 1977), 23, 98, 135, 143, 149, 219.

2 Sorun ilk olarak Sokrates (m.ö. 469-399) ve Platon'un (m.ö. 427-347) konuya iyimser yaklaşımından sonra Lactantius'un (m.s. 260-340) kendi eserinde düzenli bir şekilde aktardığı, Epikür'ün (m.ö. 341-270) kötümser yaklaşımı ve sorgulaması sonucu problemi ilk formüle edişiyle felsefî edebiyata girmiştir. Yunanca "Tanrı" ve "adalet" kelimelerinin birleşmesinden ortaya çıkan teodise kavramını ise ilk olarak Gottfried Wilhelm Leibniz (1646-1716), 1714 yılında Prusya kraliçesi Sopphie Charlotte'a ithaf ettiği Essais de Theodicee sur la bonte de Dieu, la liberte de l'homme et l'origine du mal; La Monadologie isimli eserinde kullanmıştır. Bu anlamda teodise, kötülük karşısında Tanrı'nın adaletini ve haklı olduğunu savunmak anlamına gelmektedir. (Bk. Eflatun, Theaitetos, trc. Macit Gökberk (Ankara: Millî Eğitim Bakanlığı, 1945), 75-76; Politeia, trc. Sabahattin Eyuboğlu-M. Ali Cimcoz (İstanbul: Türkiye İş Bankası Kültür Yayınları, 1999), 66; Timaios, trc. Erol Güney-Lütfi Ay (İstanbul: Sosyal Yayınları, 2001), 24-26; David Hume, Dialogues Concerning Natural Religion, trc. Mete Tunçay (Ankara: Kültür Bakanlığı, 1979), 165; Voltaire, Dictionnaire Philosophique, 4. Baskı trc. Lutfi Ay (İstanbul: İnkılap ve Aka Kitabevleri, 1973), 1: 101-102; Alfred Weber, Felsefe Tarihi, 3. Baskı trc. H. Vehbi Eralp (İstanbul: Remzi Kitabevi, 1964), 89-90, 241; John Hick, Evil and the God of Love (London: Macmillan, 1993), 5-6). 
ebde'u mimmâ kân)"33 şeklinde formüle edilen Gazzâlî’nin varlığın mükemmelliği ile ilgili görüşü, hem içerdiği anlam ve ifade tarzı bakımından, hem de Mûtezilî ve felsefî görüşlere benzerliği sebebiyle birçok sıkıntılı konuyu içerisinde barındırmasından dolayı onu eleştirilerin odağı haline getirmiş, düşünürü bu konuda savunan ve yeren birçok eserin ortaya çıkmasına vesile olmuştur. Konuyla ilgili hacimli bir araştırma yapan Eric Linn Ormsby, bu tartışmaların Gazzâlî́nin kendi zamanından başlayarak on dokuzuncu yüzyıla kadar sürdüğünü söylemekte, tartışmaya doğrudan katılan yirmi altı müellif ve on yedisi bağımsız eser olmak üzere lehte ve aleyhte yazılan kırk üç adet çalışmanın listesini vermektedir. ${ }^{4}$

Temel amaç Allah'ın adaletini, irade ve kudretini mevcut kötülükler karşısında koruma olmasına rağmen tartışmacılar ifade ettikleri düşünceler ve kullandıkları yöntemlerden dolayı birbirilerine ters düşmüş, hatta bu ifadesinden dolayı Gazzâlî́yi eleştirenler ona dinden çıkmaya kadar varan en ağır ithamları bile yöneltmekten çekinmemişleridir. Gazzâlî aleyhtarları, onun bu görüşünün, filozofların Allah'ın zâtı gereği tabiî bir zorunlulukla yaratma, aynı zamanda Mûtezile'nin yine Allah'a kulları için en iyi olanı yaratma konusunda zorunluluk atfettiği aslah görüşünden ve diğer yanlış görüşlerden kaynaklandığı iddiasında bulunmuş, söz konusu düşüncesinden dolayı onu Ehl-i Sünnet çizgisinden çıkmak gibi bir ithamla karşı karşıya bırakmışlardır. ${ }^{5}$

Konuyla ilgili görüş beyan eden âlimlerden bir kısmı bu ifadeyi kabul etmeyip inkâr etmekte, bir kısmı bunu yorumlamaya çalışmakta, diğer bir kısmı da bu sorunlu görüşün Gazzâlî́ye ait olmadığını söyleyerek onun gibi birisini böyle bir şey söylemekten tenzih etmektedir. ${ }^{6}$

3 İbrahim b. Ömer el-Bikāî (809-885/1404-1480)'ye kadar konu ile ilgili yapılan lehte ve aleyhteki çalışmalarda ifadenin aynen bu şekilde kullanımına rastlayamadık. Dolayısıyla onu ilk olarak bu şekilde Bikâî́nin kullandığını düşünmekteyiz. Şöyle ki Süyûtî, Gazzâlî́nin bu ifadesini savunduğu eserinin giriş kısmında Bikâî'nin Gazzâlî̀ye yaptığı acımasız eleştirilerini konu alan Tehdîmu'l-erkân min leyse fíl-imkân ebde'u mimmâ kân isimli bir eser yazdığını, kendisinin de bu eleştirilere karşı Gazzâlî́yi savunmak adına Teşyîdü'l-erkân fî leyse fíl-imkân ebde'u mimmâ kân isimli bir eser kaleme aldığını belirtmektedir. Daha sonra Süyûtînin eseri ile aynı isme sahip bir çalışma yapan Ebu'l-Hasan Nûreddin Ali b. Muhammed b. İsa el-Eşmûnî (ö. 929/1464) de eserinin giriş kısmında Bikâî'nin Tehdîm'ini zikrederek, onun getirdiği eleştirileri savunma amaçlı kendi eserini yazdığını ifade eder. (Bk. Celâleddîn Süyûtî, Teşyîdü'l-erkân fî leyse fí'I-imkân ebde'u mimmâ kân, Süleymaniye Kütüphanesi, Şehit Ali Paşa, nr. 2707, 70a; Ebu'l-Hasan Nûreddin Ali b. Muhammed b. İsa el-Eşmûnî, Teşyîdü'I-erkân fî leyse fíl-imkân ebde'u mimmâ kân, Süleymaniye Kütüphanesi, Şehit Ali Paşa, nr. 2707, 80a). Bikâî, bu konu ile ilgili içerik olarak ilk eserine benzeyen ikinci bir çalışma yapmış ve bunu da Delâletu'l-burhân 'alâ enne fi'l-imkân ebde'u mimmâ kân olarak isimlendirmiştir. Eserin elyazması, Semhûdî'nin eserinin de bulunduğu bir mecmua içerisinde Süleymaniye Kütüphanesi Şehid Ali Paşa bölümünde nr. 2707'de 53-68. sayfalar arasında bulunmaktadır.

4 Eric Linn Ormsby, Theodicy in Islamic Thought; The Dispute Over al-Ghazali's Best of All Possible Worlds, trc. Metin Özdemir (Ankara: Kitabiyat Yayınları, 2001), 43, 99-137.

5 Nûreddin Semhûdî, Îdâhu'I-beyân limâ erâdehu'I-Hucce min leyse fi'l-imkân ebde'u mimmâ kân, Süleymaniye Kütüphanesi, Ayasofya, nr. 2187, 2a., 3a.

6 Süyûtî, Teşyîdü'l-erkân, 70a; Ebü'I-Feyz Muhammed b. Muhammed el-Hüseynî ez-Zebîdî, İthâfü's-sâdeti'lmuttakîn bi-şerhi esrar-i Ihya-i ulûmi'd-dîn (Kahire: Matbaatü'l-Meymeniyye, 1311), 1: 33; Ahmed b. el-Mübarek, el-ibrîz min kelâmi Seyyidî Abdülaziz ed-Debbağ (b.y: Dârü'l-Fikr, ts.), 473. 
Anlaşıldığı kadarıyla, Gazzâlî́nin bu ifadesi ona saygı duyan düşünürlerin bir kısmını hayal kırıklığına uğratmıştır. Bundan dolayıdır ki, yukarıda da dediğimiz gibi bu düşünürler ya bu ifadeden dolayı Gazzâlî'nin, Mûtezile'nin ve filozofların etkisi altında kalarak büyük bir yanılgıya düştüğünü, ya da bu tartışmalı ifadenin onun eserlerine sonradan sokulduğunu söylemektedirler. Bu makalede âlemin mükemmelliğine dair görülerini aktaracağımız Şafiî fakihi, mutasavvıf, hadis âlimi, daha çok Medine tarihi ile ilgili çalışmaları ile tanınan ünlü Mısır tarihçisi Nûreddîn Ebu'l-Hasan Ali b. Abdullah b. Ahmed es-Semhûdî'nin (844/1440911/1506) de arasında olduğu diğer bir grup ise Gazzâlî́nin Ehl-i Sünnet çizgisinden çıkmadığını savunmakta ve onun bu görüşünde herhangi bir sıkıntının olmadığını iddia ederek buna açıklık getirmeye çalışmaktadırlar.

Tâcu'l-Arûs adlı eseri ile meşhur olan Murtazâ ez-Zebîdî (1145-1205/17321791) Ihyâ üzerine şerh olarak telif ettiği İthafü's-sâdeti'l-müttakîn bi-şerhi esrarı ihyâ-i ulûmi'd-dîn isimli çalışmasının birinci cildinde özet olarak, dokuzuncu cildinde ise konuyla ilgili çok geniş açıklama yaparak tartışmaya dâhil olan neredeyse tüm müelliflerin görüşlerini aktarmaktadır. ${ }^{7}$

Gazzâlî́nin çağdaşları olan Endülüslü fıkıh âlimi ve muhaddis olan Ebû Bekr Muhammed b. Velîd b. Muhammed b. Halef el-Fıhrî et-Turtûşî (451520/1059-1126) ${ }^{8}$ ve Mâlikî mezhebi fakihi, kelâm ve hadis âlimi Ebû Abdullah Muhammed b. Alî b. Ömer et-Temîmî es-Sıkillî el-Mâzerî (453-536/1061-1141) ${ }^{9}$, onu bu konuda eleştiren ilk muhaliflerden sayılmaktadırlar. Bu âlimler, Gazzâlî́yi tasavvuf ve felsefenin tehlikeli düşüncelerini kabul etmek ve bu düşünceleri Ehl-i Sünnet itikadına sokmakla suçlar ve bu konuda onu aşırı bir şekilde eleştirmekten kaçınmazlar. Kendisine Gazzâlî ve onun Ihyâ isimli eseri ile ilgili soru sorulan Mâzerî, bu eseri okumadığını ve bu konuda onun öğrencilerinin aktardıkları bilgilere dayanarak fikir belirttiğini itiraf eder. Mâzerî, Gazzâlî́nin kelâm ve usûl ilminde derin bilgi sahibi olmadığını ve düşüncelerinde İhvânu's-Safâ, İbn Sînâ ve Ebu Hayyân et-Tevhîdî (ö. 414/1023) gibi filozoflardan etkilendiğini, bu yüzden de doğru yoldan saptığını iddia eder. Turtûşî daha da ileri giderek Gazzâlî́nin Makāsıd isimli eserinde anlattığı felsefi görüşlerinde, Mi'yâru'l-'ilm adlı eserinde anlattığı mantıkla ilgili görüşlerinde İbn Sînâ'yı taklit ettiğini, fakat felsefe bilgisi derin olmayan bu adamın hiçbir zaman İbn Sînâ ile karşılaştırılamayacağını da söylemektedir. ${ }^{10}$

7 Bk. Zebîdî, ithâf, 1: 32-33; 9: 440-460.

8 Bk. Muharrem Kılıç, "Turtûşî", Türkiye Diyanet Vakfı İslâm Ansiklopedisi (İstanbul: TDV Yayınları, 2012), 41: 430431.

9 Bk. Eyyüp Said Kaya, "Mâzerî", Türkiye Diyanet Vakfı İslâm Ansiklopedisi (Ankara: TDV Yayınları, 2003), 28: 193 195.

10 Turtûşî ve Mâzerî́nin eleştirileri için bk. Şemsuddîn Ebî Abdullah Muhammed b. Ahmed b. Osman ez-Zehebî, Târîhu'l-Islâm va vafeyâtü'l-meşâhîr va'l-a'lâm, thk. Beşşar Avvad Ma'ruf (Beyrut: Dârü'l-Garbi'l-İslamî, 2003), 11: 66-68; Tâceddîn Ebî Nasr Abdulvehhâb b. Ali b. Abdilkâfi es-Sübkî, Tabakätü'ş-Şâfi'iyyeti'l-kübrâ, thk. Mahmûd Muhammed Tanâhî-Abdülfettah Muhammed el-Hulv (b.y: İsa el-Bâbî el-Halebî, 1968), 6: 240-243; Zebîdî, Ithâf, 1: 28-29, 9: 442; Lisânuddîn İbnu'I-Hatîb, el-ihâtâ fi ahbâri Gırnâta, 2. Baskı thk. Muhammed Abdullah İnan (Kahire: Mektebetü'l-Hanci, 1975), 3: 265-267. 
Gazzâlî’ye yapılan bu eleştirilerin birçoğunun sağlam delillere dayanmadığı, bazılarının da art niyet taşıdığı sezilmektedir. Nitekim Ormsby, Gazzâlî́nin filozofların, özellikle de İbn Sînâ'nın düşüncelerini aktardığı Makâsıd isimli eserini esas alarak ve onun filozofları eleştirdiği Tehâfutü'l-felâsife isimli eseri başta olmak üzere diğer eserlerinde filozoflara getirdiği eleştirilerden hiçbir alıntı dahi yapmadan onu eleştiren düşünürlerin bu tarz eleştirilerini samimiyetsiz bulmaktadır. ${ }^{11}$ Şafiî âlimi Taceddîn es-Sübkî (727-771/1327-1370) de Gazzâlî́ye yöneltilen bu eleştirilerin asılsız olduğunu, onun Eş'arî mezhebinin güvenilir âlimlerinden biri ve tasavvufta da derin bir bilgiye sahip olduğunu söyler. Sübkî yapılan eleştirilerden farklı olarak Gazzâlî́nin eserlerinde Tevhîdî'ye istinat etmediğini, onun tasavvufi görüşlerinde dayandığı esas kaynağın Ebû Tâlip el-Mekkî'nin (ö. 386/1006) Kûtu'l-kulûb ${ }^{12}$ ve Ebû'l- Kāsım el-Kuşeyrî'nin (376465/986-1072) Risâle'si olduğunu belirtir. Ayrıca ona göre eserlerinde İbn Sînâ'yı ve diğer filozofları tekfir eden ve bu konuda bir eser yazan Gazzâlî, nasıl olur da onların yolunda ilerler? ${ }^{13}$

Gerçekten de bu konuda Ormsby ve Sübkî'ye katılmamak mümkün değildir. Mâzerî'nin Gazzâlî́nin hiçbir eserini okumadan sadece duydukları ile bir görüş belirtmesi, yine Turtûşî́nin de eserlerin sadece birkaç yerinden aldığı örneklere tutunarak Gazzâlî'ye saldırması ve onun filozofları eleştirmeye ilişkin eserlerinde naklettiği düşüncelerinden hiçbir alıntı yapmaması, bu eleştirilerin objektiflik ve sağlamlık konusunda yetersiz olduğunu ortaya koymaktadır. Nitekim Gazzâlî el-Munkız'da, felsefeyle ilgilenme sebebini anlatırken bir ilmin yanlışlığının, o ilmin son noktasına kadar kavrandığı zaman ortaya çıkabileceğini, bir mezhebi anlamadan, onun inceliklerine vâkıf olmadan reddetmenin karanlığa taş atmak anlamına geldiğini ve bu yüzden de kelam ilmini bitirdikten sonra felsefeye başladığını ve bu işte hiçbir üstat ve hocadan yardım almadığını söyler. İki yıldan az bir sürede felsefenin en ince ayrıntılarını öğrendiğini söyleyen Gazzâlî, geldiği son noktanın, tüm felsefî akımların küfre düşmekten kurtulamadıklarını anlamak olduğunu belirtir. ${ }^{14}$

Aktardığımız üzere ilk başta bu eleştirilerin geneli, Gazzâlî́nin felsefeciler ve Mûtezile'den etkilendiği ve onların yöntemlerini benimsediği şeklinde seyretmekteydi. Ne var ki, XIII yüzyılda Malikî fakihi İbnü'l-Müneyyir (620683/1223-1284) konu ile ilgili kendi zamanına kadar yapılmamış daha kapsamlı ve sistemli bir şekilde ileri sürülmüş eleştirileri içeren ed-Dıyâu'l-mutele'lî fî taakkubi'l-ihyâ li'-l-Gazzâlî isimli bir çalışma yapar. Gazzâlî́nin en sağlam muhaliflerinden biri olarak bilinen ve gramer, edebiyat, tefsir, hukuk gibi birçok

11 Ormsby, Theodicy in Islamic Thought, 106.

12 Gazzâlî, el-Munkız mine'd-dalâl isimli eserinde tasavvuf terbiyesini edindiği kaynakların başında ilk olarak bu eseri zikretmektedir. Bk. Gazzâlî, el-Munkız mine'd-dalâl, trc. Abdurrezzak Tek (Bursa: Emin Yayınları, 2013), 39.

13 Sübkî'nin bu ve zikretmediğimiz benzeri eleştiriler ve onlara verdiği cevapların tamamı ile ilgili bk. Sübkî, Tabakātü'ş-Şâfi'iyyeti'l-kübrâ, 6: 240-253; Zebîdî, Ithâf, 1: 28-32.

14 Gazzâlî, el-Munkız mine'd-dalâl, 13-14. 
alanda bilgi sahibi olan İbnü'l-Müneyyir ilk başta Ihyâ'nın tamamına dair bir reddiye yazmayı düşünmüş fakat "canlılarla mücadeleyi bitirdin de ölülerle mi mücadele edeceksin?" diyen annesinin itirazı üzerine bu düşüncesinden vazgeçmiştir. ${ }^{15}$ Günümüze ulaşmayan bu eserde yapılan eleştirileri, Semhûdî, Îdâhu'l-beyân limâ erâdehu'l-Hucce min leyse fíl-imkân ebde'u mimmâ kân isimli bir eser yazarak kapsamlı bir şekilde cevaplandırmış ve bu eserinden dolayı da en etkili Gazzâlî savunmacısı olmayı başarmıştır.

Çalışmamızın temel kaynağını oluşturan Semhûdî'nin Îdâhu'l-beyân adlı eseri, yukarıda da kısaca bahsettiğimiz gibi Gazzâlî́nin "leyse fíl-imkân ebde'u mimmâ kân" şeklinde formüle edilmiş ifadesi üzerine yapılmış tartışmaları ele alan kapsamlı bir çalışmadır. İki bölümden oluşan eserin birinci bölümünde Semhûdî, Gazzâlî́nin eserlerinde bu ifadenin geçtiği metinleri aktarmaktadır. Eserin asıl tartışma konusunu oluşturan ikinci bölümünde ise bu ifadeye ilk sağlam ve sistematik eleştiri getirenlerden biri olan İbnü'l-Müneyyir'in, Gazzâlî́nin âlemin mükemmelliğine dair söz konusu ifadesinin Allah'a atfettiği zorunluluk çağırışımı, ilâhî kudreti sınırlandırması ve Mûtezile'nin hüsun ve kübuh meselesi ile benzerlik arz etmesi şeklinde ifade edilen itirazlar ele alınmaktadır. Ayrıca mükemmel ve eksiğin birlikte yaratılması, Allah'a güvenmeyi teşvik etme, Mûtezile'nin aslah teorisi ile ilgili tartışmalar, ilâhî hikmetin rolü, cömertlik ve cimrilik, adalet ve zulüm gibi meseleler de ikinci bölümde tartışılan konular arasında yer almaktadırlar. Eserde Semhûdî'nin esas amacı, İbnü'l-Müneyyir'in eleştirilerine karşı Gazzâlî́yi savunmak ve bu ifadenin yanlış anlaşıldığını ve onun Ehl-i Sünnet'ten kopmadığını kanıtlamaktır.

Netice itibariyle söylemek gerekir ki, bu çalışmanın temel maksadı, klasik anlamda bir kelamcı olarak bilinmeyen Semhûdî́nin ilgili ve bu konudaki tek eserinden hareketle âlemin mükemmelliğine dair dile getirmiş olduğu fikirlerinin özgünlüğünü değerlendirmektir.

\section{1. ÂLEMIN MÜKEMMELLIĞi DÜşÜNCESi}

Semhûdî́nin âlemin mükemmelliği düşüncesi bağlamında dile getirdiği fikirleri anlamlı kılan çerçeve, İbnü'l-Müneyyir'in Gazzâlî'ye dair sergilemiş olduğu eleştirilere karşı geliştirilen savunma çizgilerinden oluşmaktadır. Bu hakikatten hareketle söylemek mümkündür ki, Semhûdî'nin söz konusu eserinin temel niteliğini belirleyen ana kaygı, özellikle bir teodise inşa eylemek değil, Gazzâlî́nin kelâmî düşünceye yenilikler katarak gerçekleştirdiği ve âlemin mükemmelliğini ispat etmek üzere kullandığı argümanların yetersizliğine dair İbnü'l-Müneyyir'in dile getirdiği eleştirilerin anlamsızlığını kanıtlamaya çalışmaktan ibarettir. İşbu nedenle, eserde sistematik bir teodise ile karşılaşmamaktayız. Semhûdî'nin bu konudaki fikirleri, Gazzâlî́nin görüşlerini açıklarken ve onu itirazlara karşı savunurken ifade ettiği düşüncelerden oluşmaktadır.

15 Semhûdî, Îdâh, 2a.; Süyûtî, Kitâbu Buğyetü'l-vu'ât fî tabakâti'l-luğaviyyîn ve'n-nuhât (Kahire: Matbaatü's-Saade, 1326), 168.; Ormsby, Theodicy in Islamic Thought, 113. 
Belirtmek gerekir ki, İbnü'l-Müneyyir'in eleştirileri de hem Semhûdî'nin teodise ile ilgili görüşlerinin ortaya çıkması hem konunun bu kadar geniş bir yelpazede ele alınması hem de daha sonraki tartışmacılara malzeme oluşturması bakımından azımsanmayacak bir önem arz eder.

Tartışmaya başlamadan önce konuya açıklık getirme amacıyla Gazzâlî́nin, âlemin mükemmelliği ile ilgili büyük tepkilere neden olan görüşünü kısaca özetlemekte fayda vardır:

Hayır ve şer takdir edilmiştir. İlâhî iradenin ezelde takdir etmesinin ardından takdir edilen her şeyin meydana gelmesi zorunludur. Hiçbir kuvvet Allah'ın hükmüne karşı gelemez, hiç kimse O'nun takdirini ve emrini değiştiremez. Küçük ve büyük her şey ezelde takdir edilmiştir ve takdir edildiği şekliyle de olacaktır. ${ }^{16}$

Rızık, ecel, mutluluk, hüzün, acziyet, kudret, iman, küfür, itaat ve isyan gibi Allah tarafından insanlara bağışlanan şeyler tamamen adalet üzerine olup, asla zülüm ve haksızlık içermemekte, bilakis bunlar hepsi en mükemmel ve güzel şekilde, olması gerektiği gibi, olması gerekene uygun, olması gerektiği ölçüde zorunlu hak düzene göredir. İmkân dâhilinde bundan daha mükemmel, daha tam ve daha iyi, hiçbir şey yoktur. Eğer daha mükemmeli olsaydı ve Allah'ın kudreti dâhilinde olduğu halde bunu yaratmayıp esirgeseydi, bu cömertliğe zıt olan cimrilik, kudrete zit olan acziyet ve adalete zıt olan bir zulüm olurdu. Ve yine eğer Allah'ın bunu yapmaya gücü yetmeseydi, bu da ulûhiyete ters olan âcizlik olurdu. ${ }^{17}$

Bu dünyadaki her türlü fakirlik ve zarar, bu dünyada eksiklik, âhirette ise artıştır. Şöyle ki, gece olmasaydı gündüzün değeri bilinmezdi, hastalık olmasaydı sağlıklı insanlar sıhhatten keyif almazlardı, cehennem olmasaydı cennet ehli nimetin değerini bilmezdi. Ayrıca hayvanların ruhlarının insanların ruhlarına feda edilmesi ve insanlara onları kesme yetkisinin verilmesi; cehennem ehlinin azabını artırarak cennet sakinlerine nimetin bol bol verilmesi ve küfür ehlinin iman ehline feda edilmesi; insan hayatını kurtarmak için kangren olmuş elin kesilmesi gibi mükemmel olanın eksik olana tercih edilmesi durumları zulüm değil, bilakis adaletin ta kendisidir. ${ }^{18}$

Sonuç olarak ilâhî iradenin ezelde takdir ettiği ve bu takdirin ardından var olması zorunlu olan bu âlem, şekil olarak mümkün âlemlerin en mükemmeli, tasarımı en güzel olanı ve yaratılış açısından en kusursuz olanıdır. ${ }^{19}$

Bu dikkat çekici ve iddialı düşünce, Gazzâlî́nin, kendisi henüz hayattayken birçok çağdaşı tarafından eleştirilmesine neden oldu. Yapılan ilk itirazlardan biri,

16 Gazzâlî, İhyâ, 4: 253.

17 Gazzâlî, îhyâ, 4: 252

18 Gazzâlî, lhyâ, 4: 252-253.

19 Gazzâlî́nin âlemin mükemmelliğine dair görüşleri ile ilgili geniş bilgi için bk. Gazzâlî, Ihyâ, 4: 252-253; Gazzâlî, Kitâbu'l-Erbaîn, 307-312; Gazzâlî, el-İmlâ fî işkâlâti'I-ihyâ, 6: 235. 
onun bu ifadesinin Filozofların ve Mûtezile'nin yaratılış ve kul için en uygun olanı yaratması gibi konularda Allah'a zorunluluk atfetme düşüncesinden farklı bir sonucu doğurmadığı ve bu konuda Gazzâlî'nin onlardan etkilendiği iddiasıdır. Daha sonra bu ilk iddiayı, aşağıda İbnü'l-Müneyyir üzerinden tartışacağımız, düşüncenin felsefî ve Mûtezilî görüşlere benzerliği, ilâhî kudreti sınırlandırması vs. gibi çeşitli eleştiriler takip eder.

Bu çalışmadaki temel hedef, İbnü'l-Müneyyir'in eleştirilerinin anlatımından daha ziyade, Semhûdî'nin Îdâhu'l-beyân'da parçalar halinde var olan ilgili düşüncelerini bir araya getirerek Semhûdî savunmasının ve teodisesinin temel niteliklerini ortaya koymak ve bir kompozisyon oluşturmaktır. Bu düşünceleri fonksiyonel olarak aşağıdaki şekilde bir araya getirebiliriz.

\subsection{Yaratılması Zorunlu Âlem}

Gazzâlî ile bu konuda aynı görüşü paylaşan Semhûdî'ye göre bu âlem, Allah'ın bilgisi ve iradesinin takdiri ile mümkün âlemler içerisinden hür bir irade ile seçilmiş, bilgi ve hür iradenin ezelde takdirinden dolayı hikmet gereği yaratılması zorunlu hâle gelen en mükemmel âlemdir. Fakat buradaki "yaratılması zorunlu hale gelen" tabiri, İbnü'l-Müneyyir ve diğer muhalifler tarafından keskin bir dille eleştirilmiştir. Nitekim İbnü'l-Müneyyir bu düşüncenin, Allah'ın ihtiyarî olarak değil de zâtı gereği yarattığını söyleyerek ona zorunluluk istinat eden filozofların görüşleri ile aynı olduğunu ve bundan dolayı da batıl bir görüş olduğunu iddia etmektedir. Semhûdî ise söz konusu iddiaya karşın bu ifadeden Allah'ın özgürlüğünü kısıtlayıcı ve O'nu bir eylem yapmaya zorlayıcı bir durumun ortaya çıkmasının söz konusu olmadığını belirterek ${ }^{20}$ iddiasını desteklemek amacıyla Gazzâlî'nin Ihyyâ'da yer alan, şu görüşünü nakleder:

"Bunlar hepsi olması gerektiği gibi, olması gerekene uygun, olması gerektiği ölçüde zorunlu hak düzene göredir". ${ }^{21}$

Düşünür, "zorunlu hak düzene göre" ifadesinde geçen zorunluluk kavramının, Allah'ın fâil-i muhtar olmasına ters düşecek bir anlamda kullanılmadığını, O'nun özgürlüğünü kısıtlayıcı ve O'nu bir eylem yapmaya zorlayıcı bir durumu ortaya çıkarmadığını belirtir. Bilakis burada kastedilen, ortaya çıkması kaçınılmaz olan takdir edilmiş bir düzendir. Semhûdî bu iddiasını Gazzâlî́nin İhyâ'daki şu görüşüyle teyit etmeğe devam eder:

"Ilâhî iradenin ezelde takdir etmesinin ardından takdir edilen her şeyin meydana gelmesi zorunludur"22.

20 Semhûdî, Îdâh, 5b, 6a, 7a-7b, 34a-34b.

21 Gazzâlî, İhyâ, 4: 252.

22 Gazzâlî, İhyâ, 4: 253; Semhûdî, Îdâh, 5b, 6a. 
Semhûdî’ye göre Gazzâlî’nin bu ifadesindeki "meydana gelmesi zorunludur" tabiri ile anlatılmak istenen, ilâhî bilgi ve iradenin takdirinin sonucu olarak ortaya çıkan bir durumdur. Çünkü ilâhî bilgi ve irade tarafından takdir edilen bir düzenin yaratılması kaçınılmaz olarak zorunlu olmaktadır. Şöyle ki, Semhûdî'ye göre bu zorunluluğu, Allah'ın eylemde bulunması konusunda seçme özgürlüğü ve bu seçimin akabinde gelen Allah'ın hikmeti gereği en mükemmel şekilde ortaya çıkma zorunluluğu olarak algılamamız gerekmektedir. İlâhî iradenin tam anlamıyla etkisi, iradeye bağlı olan ilâhî kudret, Allah'ın lütuf ve nimetleri ile beliren cömertliği ve eşyayı hak ettiği yerine koymayı gerektiren hikmeti, bu zorunluluğu gerekli kılan başlıca etkenlerdir. İşbu sebepten dolayı burada zorunluluk dışında herhangi bir durumun ortaya çıkması imkânsızdır. Bu durum, O’nun yüceliğini ve sıfatlarının mükemmelliğini göstermektedir. Bunun için de insanlar Allah'a tam anlamıyla güvenmekte, başlarına gelenlere rıza göstermekte, üzerlerine düşeni yaptıktan sonra da işlerinin sonucunu O'na havale etmektedirler. ${ }^{23}$

Semhûdî, Gazzâlî́nin söz konusu ifadesinde Allah'ın fâil-i muhtâr olduğunu kısıtlayacak herhangi bir durumun olmadığını iddia ederek bu iddiasını kanıtlamak amacıyla aksini kabul etmemizin bizi âlemin ezeliliğine götürdüğü yaratmanın ertelenmesi ${ }^{24}$ konusu ile dünyanın en mükemmel bir şekilde yaratılması gibi birbirine benzer iki olayı karşılaştırmaktadır. O, âlemin yokluktan varlık alanına getirilmesinin ertelenmesi durumunu Allah'ın özgürce seçimine bağlamaktadır. Bu durumda, Allah'ın âlemi yaratmayı ertelemesi konusunda herhangi bir sıkıntı söz konusu olamaz. Çünkü hikmetinin gerektirdiği bu durum Allah tarafından onun mutlak iradesi ile özgürce seçilmiştir. Bu yüzden de bu bizi, O'nu cimrilikle, acziyet ve adaletsizlikle suçlamaya götürmemektedir. Şöyle ki, fâil-i muhtâr olan Allah yaratmayı da yaratmamayı da seçebilir. Yaratmayı seçmesi durumunda da bu yaratma, hikmetinin gerektirdiği en mükemmel şey şeklinde tezahür etmektedir. Nasıl ki, Allah'ın dünyayı istediği bir zamanda yaratması onun hür seçiminin ve mutlak iradesinin bir sonucu olarak ortaya çıkmaktaysa, aynı zamanda yaratmasındaki mükemmel düzey de hikmetinin gerektirdiği bir

23 Semhûdî, Îdâh, 6a.

24 Âlemin hâdis olması ile ilgili kelamcılar arasında genel görüş birliği olsa da mütkeaddimûn kelamcılardan nadir de olsa Allah'ın fiilinin hâdis olması gerektiğini belirtmekle beraber, madde-suret teorisinin kelama uyarlanarak kullanılmasının sonucunda ortaya çıkan âlemin kadim olmasının aklen mümkün olduğu görüşünü ileri sürenler de olmuştur. Cürcânî́nin, Âmidî ve Îcî tarikiyle aktardığı bu düşünceye göre, iradeye dayalı bir yaratmanın yaratılanın varlığını öncelemesi ile zorunlu bir yaratmanın yaratılanın varlığını öncelemesi birbirine benzemektedir. Şöyle ki, zorunlu yaratmadaki önceliğin zaman bakımından değil zât bakımından olması durumunu seçime dayalı yaratmaya da şamil ede biliriz. Yani iradeye bağlı olarak yaratılan zaman bakımından aynı olsa da zât bakımından daha sonradan gelebilir ve sonuç olarak âlemin ezelde zorunlu olması ile birlikte Allah'ın fâil-i muhtâr olması aynı anda mümkündür. Bu durum, elin hareketinin, yüzüğün hareketiyle zaman bakımından aynı olmasına rağmen zât bakımından onu öncelemesine benzemektedir. Sonuç olarak varlıkta beraber olan Allah ve âlem arasında zât bakımından öncelik ve sonralık ilişkisi bulunmakta ve âlemin kadim olması ile Allah'ın muhtar olması çelişmemektedir. Yukarıda bahsettiğimiz bazı kelamcılar tarafından mümkün görülen bu düşünce genel olarak kabul görmemiş ve benimsenmemiştir. (Geniş bilgi için bk. Cürcânî, Şerhu'l-Mevâkıf, trc. Ömer Türker (İstanbul: Türkiye Yazma Eserler Kurumu Başkanlığı, 2015), 1: 436, 728-748; Neşredenin girişi, 1: 23, 74-77). 
şey olup Allah'a herhangi bir zorunluluk atfetmez, bilakis onun hür seçiminin ve mutlak iradesinin bir sonucu olarak ortaya çıkmaktadır. ${ }^{25}$

Sonuç olarak Semhûdî'nin burada zorunlulukla kastettiği, Allah'ın ezelde takdir ettiğinin ve var olmasını bildiği nesnelerin zamanı gelince var olmasının zorunluluğudur. Aksi halde bu durum, O'nun ilminin cehalete dönüşmesi anlamına gelen imkânsız olan bir durumun ortaya çıkmasına neden olur. ${ }^{26}$

Zorunlulukla ilgili bu tartışmada Semhûdî'nin daha tutarlı olduğu anlaşılmaktadır. Şöyle ki, düşünürün burada temel kaygısı ve odaklandığı esas nokta ezelî ilme eksiklik atfedilmemesidir. Nitekim, İbnü'l-Müneyyir ve onunla aynı görüşü paylaşanların, buradaki zorunluluk kavramını Allah hakkında sıkıntılı olarak görmelerinin temel sebebinin, onların konuya daha derinlemesine değil, yüzeysel olarak yaklaşmaları olduğunu söyleyebiliriz. Gayet açıktır ki, Allah'ın bir şeyin olacağını önceden bilmesi ve bunu takdir etmesi, O'nun zâtı gereği yarattığına değil, bilakis ilim ve irade iş birliği sonucunda o şeyin ortaya çıkacağının zorunlu olmasından başka bir şeye delalet etmez.

\subsection{Mükemmel ve Eksiğin Birlikte Yaratılması}

Yukarıda aktardığımız pasajlardan Gazzâlî́nin, eksik olanın yaratılmasının, mükemmelin bilinmesi için çok önemli olduğunu düşündüğünü görmekteyiz. Semhûdî, Gazzâlî'nin söz konusu görüşünü onaylayarak eksik olanın yaratılmasının, en mükemmel âlem için hikmetin gerektirdiği bir şey olduğunu söyler. Bu yüzden de tüm mükemmellikler ve eksiklikler hikmetin gerektirdiği şekilde ve zamanda birlikte var olmakta ve hikmetin gerektirdiği bu eksiklikler de en mükemmel bir düzenin vazgeçilmez bir parçası sayılmaktadırlar. ${ }^{27}$ Semhûdî burada düşüncesini Gazzâlî'nin İhyâ'daki şu ifadesi ile destekler:

"Eksik olan yaratılmasaydı, mükemmel olan bilinmezdi. Hayvanlar yaratılmasaydı insanın şerefi belli olmazdı. Gerçekten de mükemmellik ve eksiklik görecelidir. Ilahî cömertlik ve hikmet, eksik ve mükemmel olanın birlikte yaratılmasını gerektirmektedir." ${ }^{18}$

İbnü'l-Müneyyir, buna karşı çıkarak mükemmel olanı bilmeye ihtiyacımızın olmadığını, hatta insan için mükemmelin farkında olmamanın belki de en iyisi olduğunu iddia eder. Ayrıca düşünür, eksik olandan yola çıkarak mükemmeli bilme düşüncesini de kabul etmemektedir. Mükemmeli eksiklikten dolayı bilme durumunun Allah hakkında imkânsız olduğunu ifade eden İbnü'l-Müneyyir'e göre biz Allah'ın mükemmelliğini, O'nun hakkında imkânsız olan eksiklikten yola çıkarak değil, aklımıza herhangi bir noksan getirmeden sırf mükemmel olarak biliyoruz. Eğer, “biz Allah'ın mükemmel olmasını yaratılanların eksikliğinden yola

25 Semhûdî, Îdâh, 6b, 7a.

26 Semhûdî, l̂dâh, 7a.

27 Semhûdî, Îdâh, 8a.

28 Gazzâlî, İhyâ, 4: 253. 
çıkarak biliyoruz" denirse, bu itiraza cevap olarak Allah'ın daha ilk başta insanları mükemmelin bilgisi ile yaratabileceğini söyleyebiliriz. Bu konuda çeşitli sorular sorarak eleştirisini geliştirmeye çalışan İbnü'l-Müneyyir şöyle der: Biz eksik olandan yola çıkarak mükemmeli bildiğimizi kabul etsek bile, sonradan yaratılmış olması eksikliğe ve aynı zamanda Allah'ın mükemmelliğine işaret eden mahlukat örneği bunun için yeterli olmaz mıydı? Ayrıca kör ve sağır olanın yaratılmasına ne gerek vardı? Eksik olan bir örneğin yaratılması mükemmelin bilgisine ulaşmak için yeterli değil mi? Mahlukattan eksik olanların mükemmel olanlarından daha fazla olmasını nasıl anlamlandıralım? ${ }^{29}$

Semhûdî, bu eleştirileri yanıtlarken ilk başta söylediğimiz, "tüm mükemmellikler ve eksiklikler hikmetin gerektirdiği şekilde birlikte var olmakta ve hikmetin gerektirdiği bu eksiklikler en mükemmel bir düzenin olmazsa olmazı addedilmektedir" görüşünü yineleyerek getirilen eleştirilerin, eksik olanın yaratılmasında ilâhî hikmetin rolünü yok saymaya ve Allah'ın yaratmakta hikmet sahibi olmadığı sonucuna götürdüğünü söyler. Ona göre bu, ilâhî hikmeti tenzih etmemiz gereken bir durumdur. Bu tarz bir yaratılışın dünya hayatının nizamına da hizmet ettiğini ifade eden müellifimize göre Allah dilerse eksiği değil sadece mükemmeli yaratabilirdi. Altın ve gümüşün taştan daha mükemmel olduğu aşikardır. Allah eğer dilerse tüm dağları altın ve gümüşten yaratabilirdi. Fakat alemin mevcut hali en mükemmel olanıdır. Çünkü eğer tüm dağlar altın ve gümüşten olsaydı insanlar geçimlerini sağlamak için meslekler edinmeye ihtiyaç duymazlardı. Allah dünya hayatının nizamı için insanların sıradan da olsa farklı meslekler edinmelerini istemektedir. ${ }^{30}$ Semhûdî, iddiasını İbn Atâullah el-İskenderî́nin (ö. 709/1309) bu konu ile ilgili görüşünü aktararak güçlendirmeye çalışır:

"Yoksulların varlığı zenginler için Allah'ın bir nimetidir. Çünkü onlar dünyada kazandıklarını ahirete taşıyacak birini bulmuşlardır. Yoksullar eğer onların verdiklerini alırlarsa Allah da bunun karşılığında onları ödüllendirir. Eğer Allah fakirleri yaratmasaydı zenginler sadakalarını verecek ve karşılığında onları sevaba götürecek birisini nasıl bulacaklardı? Nitekim kişinin sadakasını verecek birini bulamaması kıyâmet alametlerinden sayılmaktadır." ${ }^{\prime \prime 1}$

Açıklamalarına devam eden Semhûdî, İbnü'l-Müneyyir'in "mükemmeli bilmeye ne gerek var" şeklindeki itirazına cevap verirken, dinî yükümlülüklerden sorumlu olanlar için mükemmeli ve eksiği bilmenin yaratıcıya şükretme sebeplerini anlama açısından bir ihtiyaç olduğunu söyler. Aynı zamanda Semhûdî'nin, "insan için mükemmelin farkında olmamanın en iyisi olduğu" şeklindeki iddiaya verdiği cevap da aynı mantığa dayanır. Şöyle ki, eğer insan mükemmelin farkında olmazsa belaya uğramış birini gördüğünde bunun kendisine isabet etmemesinden dolayı

29 Semhûdî, Îdâh, $31 \mathrm{a}$.

30 Semhûdî, Îdâh, 31a-31b.

31 İbn Atâullah el-İskenderî, et-Tenvîr fî iskâti't-tedbîr (Beyrut: Dârü'l-Kütübi'l-ilmiyye, 1998), 53; Semhûdî, Îdâh, 31 b. 
yaratıcıya şükretmesi gerektiğini nasıl anlayabilir? Mükemmeli eksik olandan yola çıkarak bilme düşüncesinin yanlışlığına gelince, Semhûdî bunu kesinlikle kabul etmez. Şöyle der Semhûdî: Sebepleri sonuçlara bağlamaya yardımcı olan Allah'ın koyduğu bu yasalar sayesinde biz, görünen bir zıddın ortaya çıkardığı kendi zıddının mükemmelliğini ve güzelliğini anlar ve Allah'ın nimetlerinin farkında olmama gafletinden uyanırız. ${ }^{32}$

Semhûdî Allah'ın neden örnek olsun diye bir körü veya sağırı yaratmadığı şeklindeki eleştiriyi cevaplarken ilâhî hikmetin bu gibi örneklerin fazla olarak yaratılmasını ve yaygın olmasını gerektirdiğini ifade eder. Bu gibi eksik yaratılmanın fazla olması insanlara Allah'ın nimetlerini daha çok hatırlatır ve kendi durumlarına bakarak daha çok şükretmelerini sağlar. Eksik yaratmanın az olması veya tek bir örnek olması bu amaç için yeterli değildir. Bilakis bu durumda hikmete uygun olan eksik yaratmanın fazla olmasıdır. Ayrıca Allah'ın varlıklarda yarattığı çeşitli mükemmellik ve eksiklik sıfatları da bir amaca yöneliktir. Şöyle ki hikmet, insanların başkalarının müptela olduğu bu eksiklikleri gördükleri zaman bunun neden çok olduğunu sorgulasınlar diye değil, kendilerinden daha şiddetli sıkıntılara maruz kalanlara bakarak kendi durumlarına üzülmesinler ve Allah'ın kendilerini daha ağır belalarla karşı karşıya bırakmadığı için şükretsinler diye böyle bir yaratmayı gerektirmektedir. ${ }^{33}$

Özet olarak söylemek gerekirse Gazzâlî gibi Semhûdî de ilâhî cömertlik ve hikmetin gerektirdiği mükemmel olanla eksik olan arasında var olan direkt ilişkinin önemini vurgulamaktadır. Bu ilişki onlar için en mükemmel âlem teorisinin olmazsa olmazı sayılır. Özellikle de ilâhî hikmet, hemen hemen her açıklamasında Semhûdî'nin elinden tuttuğu ve onun için büyük önemi hâiz bir yardımcısıdır. Bu yüzden de ilâhî hikmet ve cömertlik konusunu ayrıca bir başıık altında özet olarak değinmekte fayda olduğu kanaatindeyiz.

\section{3. İlahî Hikmet, Cömertlik ve Adalet}

Yukarıda değindiğimiz gibi, Semhûdî teodisesinin muhaliflerin sıkıntılı olarak gördükleri hemen hemen her sorununun çözümünde ilâhî hikmet merkezî bir yer tutmaktadır. Belirtmek gerekir ki, Gazzâlî gibi Semhûdî'nin de ilâhî hikmete yüklediği anlam onu Eş'arîlik'ten daha ziyade, Mâtürîdî çizgiye yaklaştırmıştır. Bize göre bu durum, Semhûdî için, Allah'ın fillerinde herhangi bir amaç maksat ve

32 Semhûdî, Îdâh, 31b-32a.

33 Semhûdî, Îdâh, 32a-32b. 
hikmet aramayan Eş'arî ilahî hikmet anlayışına ${ }^{34}$ bağlı kalarak bu tarz bir teodise oluşturmanın uygun olmamasından kaynaklanmaktadır. Zira akla daha çok önem veren Mâtürîdî anlayış bu anlamda daha elverişlidir.

Semhûdî çalışmasının henüz ilk sayfalarında ilahi hikmeti bu anlamda devreye sokar ve sona kadar kullanmaktan hiç vazgeçmez. Şöyle ki, Semhûdî eserinin başlarında muhaliflerin, Gazzâlî́nin ifadesinden var olandan daha iyi olanın yaratılmasının, Allah'ın kudreti üzerinde olduğu anlamının çıktığı şeklindeki bir itirazını dile getirirken, ifadenin bu şekilde anlaşılmadığını ve bu konunun ilâhî hikmet ve cömertlik açısından değerlendirilmesi gerektiğini söyler. ${ }^{35}$ Bu konu ileride müstakil bir başlık altında anlatılacaktır. Şimdi İbnü'l-Müneyyir'in, karşı çıktığı Gazzâlî́nin "Allah, daha iyi bir dünya mevcut olsaydı bunu yaratmayıp esirgemesi halinde cimrilik ve zulüm yapmış olurdu" ${ }^{\prime \prime 6}$ şeklindeki iddiasına Semhûdî'nin yine ilahî hikmeti devreye sokarak nasıl cevaplandırdığını anlatmaya çalışalım.

Konuya kavramsal bir bakış açısıyla yaklaşan İbnü'l-Müneyyir'e göre Allah hakkında cömertliğin yokluğu, var olması imkânsız olan salt bir olumsuzluktur.

34 Eş'arîler Allah'ın fiillerinde hikmet olduğunu kabul ederler, fakat bu konuda Allah’ın hikmetsiz bir eylemde bulunmayacağını ve onun fiillerinin hikmet dairesi dışına çıkmayacağını söyleyen Mâtürîdîyye ve yine Allah'ın hikmetsiz ve maksatsız bir eylemde bulunmayacağını, hikmetsiz ve amaçsız bir eylemin de sefeh ve abes olduğunu söyleyen Mûtezile'den farklı bir anlayışı benimsemektedirler. Onlara göre Allah'ın fiillerindeki bu hikmet zorunlu değil, cevaz suretiyledir. Mahlukatın yaratılmasında hikmet sahibi olan Allah, mahlukatı yaratmasa da yarattığını fazlasıyla yaratsa da bu, O’nun için caiz olup hikmetten çıkma gibi bir durum söz konusu değildir. Aynı zamanda sadece kafirleri veya sadece müminleri yaratması, bunun yanı sıra sadece cansızları veya sadece canlıları yaratması da caizdir. Tüm bu durumlar hikmetsizlik olarak değil, bilakis doğruluk, adalet ve hikmet üzere meydana gelmektedir. Allah'ın fiilleri herhangi bir amaç, maksat, sebep ve hikmetle muallel değildir. O'nun fiillerini bir takım maksat, sebep ve hikmetlere bağlı kılmak bir eksiklik olup, Allah’ı şânına aykırıdır. Şöyle ki, bir fiili bir maksat ve hikmete göre işlemek, bu maksat ve hikmetle eksik olanı tamamlamak anlamına gelir. Bu takdirde maksat ve hikmet faili mükemmel hale getirmekte ve onu tamamlamaktadır. Bu durumda Allah'ın fiilleri bir maslahat elde etmek veya bir fesadı gidermek gibi bir amaçtan dolayı olmuş olsaydı, $\mathrm{O}$, zâtı nedeniyle eksik olur, bu amaçtan dolayı yetkinleşirdi. Allah ise bu gibi eksiklikten münezzehtir. Bunun yanı sıra eğer Allah’ın fiillerinin hikmet ve maslahata bağlı olması gerekseydi, varlığında hiçbir fayda bulunmayan hastalıkların ve zararlı hayvanların yaratılmaması gerekirdi. (Îtikādî mezheplerin hikmete dair görüşleri ile ilgili bk. Eş’arî, Makālâtü'l-islâmiyyîn ve ihtilâfu'l-musallîn, trc. Mehmet Dalkılıç-Ömer Aydın (İstanbul: Kabalcı Yayınevi, 2005), 213; Mâtürîdî, Kitâbu'ttevhîd, trc. Bekir Topaloğlu (Ankara: Türkiye Diyanet Vakfı İslam Araştırmaları Merkezi (ISAM) Yayınları, 2002), 77, 276-279; Ebû Bekr Muhammed b. Tayyib el-Bâkıllânî, et-Temhîd fi'r-red 'ale'I-Mülhideti'l-Mu'attıla va'r-Râfidati va'l-Hâvâric va'I-Mûtezile (Kahire: Dârü'l-Fikri'l-Arabî, 1947), 50-52; Kadı Abdulcebbâr, el-Muğnî fî ebvâbi't-tevhîd ve'l-adl, thk. Mahmûd Muhammed Hudayrî (Kahire: ed-Darü'l-Mısriyye, 1963), 5: 222; Ebü'l-Yüsr Muhammed Pezdevî, Usûlu'd-dîn, trc. Şerafeddin Gölcük (İstanbul: Kayıhan Yayınevi, 1980), 62-63, 72, 180, 185-186; Nesefî, Tebsıratü'l-edille, 2. Baskı thk. Hüseyin Atay (Ankara: Diyanet İşleri Başkanlığı Yayınları, 2004), 1: 504-507; Nesefî, Kitâbu't-temhîd li kavâidi't-tevhîd, trc. Hülya Alper (İstanbul: İz Yayıncılık, 2007), 60; Şehristânî, Nihêyetü'l-ikdâm fî ilmi'l-kelâm, thk. Alfred Guillaume (London: Oxford University, 1934), 397-398; Şehristânî, el-Milel va'n-nihal, trc. Mustafa Öz (İstanbul: Litera Yayıncılık, 2008), 58; Sâbûnî, el-Bidâye fí usûli'd-dîn, 10. Baskı trc. Bekir Topaloğlu (İstanbul: Marmara Üniversitesi Illahiyat Fakültesi Vakfı Yayınları, 2012), 123; Seyfuddin Âmidî, Gāyetü'l-merâm fí ilmi'l-kelâm, thk. Hasan Mahmûd Abdüllatif (Kahire: Vizaretü'l-Evkaf, 1971), 224; Ebû Saîd Abdullah b. Ömer b. Muhammed Beyzâvî, Tavâli'u'l-envâr min metâli'i'l-enzâr, trc. İlyas Çelebi-Mahmut Çınar (i̇stanbul: Türkiye Yazma Eserler Kurumu Başkanlığı Yayınları, 2014), 212, 214; Cürcânî, Şerhu'l-Mevâkıf, 3: 350-358; Abdurrahîm b. Ali Şeyhzâde, Nazmu'l-ferâid va cem'u'l-fevâid (Kahire: Matbaatü'l-Edebiyye, h. 1317), 27; Seyyid Bey, Usûl-i Fıkıh (İstanbul: Karabet Matbaası, 1338, 2: 246).

35 Semhûdî, Îdâh, 2 b.

36 Gazzâlî, îhyâ, 4: 252-253. 
Çünkü cömertlik O’nun zâtında bulunan sübûtî bir sıfat değil, fiillerine yönelik bir sıfattır. Böyle olduğu takdirde fiillere yönelik bir sıfat olan cömertliğin yokluğu O'nun hakkında cimrilik sıfatını nasıl gerektirebilir? Bir eylemde bulunurken cömert olan Allah, âlemi en mükemmel bir şekilde yaratmasaydı, hatta hiç yaratmasaydı bile bu, O'nun cimrilikle nitelenmesini gerektirmezdi. ${ }^{37}$

Semhûdî burada eksiklik olarak tabir edilen cimrilikle, cömertliğin soyut olarak terk edilmesinin değil, daha iyi bir âlemin mevcut olması halinde Allah'ın bu âlemi değil de ondan daha az mükemmel olanı yaratmasının doğurduğu bir cimrilik halinin kastedildiğini söyler. Çünkü bu Allah'ın, hikmetinin gerektirdiği en mükemmel olan bir âlemi yaratabileceği halde, bunu yapmayarak esirgemesi anlamına gelmektedir. Şöyle ki, âlemin mevcut halinden daha mükemmeli olsaydı, Allah da bunu yaratmayarak esirgeseydi, bu durum yaratmadaki hikmetine aykırı düşmüş olurdu ki, hikmetinin gerektirdiğinin tersine olan bir fiili yapmaktan Allah'ın tenzih edilmesi gerekir. Sonuç olarak burada cömertlikle kastedilen anlam, Allah'ın hikmetinin gerektirdiği en iyi şekilde yaratması, cimrilik ise onu tenzih etmemiz gereken yaratmada hikmetinin gerektirdiğine aykırı bir şekilde davranmasıdır. ${ }^{38}$

İbnü'l-Müneyyir, söz konusu ifadeye karşı çıktığı diğer bir delilinde, cömertlikle cimrilik, aynı zamanda adaletle zulüm arasında, siyahlık ve beyazlık gibi sıfatlar arasında var olan tarzda bir zıtlığın olmadığını iddia etmektedir. Şöyle ki, ona göre cimriliğin, aynı zamanda zulmün kötü olması, yine cömertliğin ve adaletin iyi olması şer'î hükümlerdir ve şeriatın cimrilik hakkında iyi, cömertlik hakkında da kötü olarak hüküm vermesi mümkündür. Sonuç olarak İbnü'l-Müneyyir, Allah yaratmada cömert davranmayabilir, fakat bu durum bizim onu cimri olarak nitelendirmemizi gerektirmez demektedir. ${ }^{39}$

Semhûdî, böyle bir iddiada bulunan İbnü'l-Müneyyir'i aklın, kemal sıfatlarından olan cömertliğin ve adaletin güzelliğini, noksan sıfatlarından olan cimriliğin ve zulmün kötülüğünü, aynı zamanda kemal sıfatlarının Allah hakkında kullanılmasını, noksan sıfatlardan da onu tenzih etmeyi idrak etmede bağımsız olması konusunda gaflet içerisinde olmakla suçlar. ${ }^{40}$ Nitekim aklın kendi başına yetkinlik ve eksiklik sıfatlarını idrak edebildiği ve bunun şeriatla hiçbir ilgisinin bulunmadığı konusunda âlimlerin görüş birliği içerisinde olduğunu ifade eden Semhûdî, kemal sıfatlarından olan ilim ve adaletin güzel, noksan ifade eden sıfatlardan olan cehaletin ve zulmün kötü olmasını, aynı zamanda kemal sıfatlarının Allah hakkında kullanılmasını, noksan sıfatlardan da onu tenzih etmeyi aklın idrak etmesi konusunda âlimler arasında hiçbir ihtilafın bulunmadığını söylemektedir. Bu düşünceden yola çıkarak da Allah'ın ezelî ilminde var olacağının bilgisi olan bir

37 Semhûdî, Îdâh, 8a.

38 Semhûdî, Îlâh, 8a-8b.

39 Semhûdî, Îdâh, 8a.

40 Semhûdî, Îdâh, 8b. 
şeyin var olmasının zorunlu, var olmamasının da imkânsız olduğu, aksi durumda Allah hakkında bilgisizlik gibi bir durumun ortaya çıkması ve bundan da Allah'ın münezzeh olduğuna dair de görüş birliği bulunmaktadır. ${ }^{41}$ Semhûdî, bu eleştiriye de yukarıdakine benzer bir şekilde ilahi hikmet odaklı cevap vererek burada Gazzâlî́nin iddiasını bina ettiği şeyin tamamen farklı olduğunu ve onun kesinlikle, Allah'ın herhangi bir yaratma anında cömert davranmamasının O'nu cimrilikle nitelendirmemizi gerektirdiğini kastetmediğini ifade eder. O’na göre Gazzâlî́nin cimrilik tabiriyle anlatmak istediği, ilâhî hikmetin, yaratmada cömertliği gerektirmesi halinde Allah'ın böyle davranmayıp bunu esirgemesidir. ${ }^{42}$

Cömertlik ve cimrilik konusuna dair yönettiği bir diğer itirazında İbnü'lMüneyyir, Gazzâlînnin, "Allah, eğer dünyanın mevcut halinden daha mükemmeli olsaydı ve onu yaratmasaydı bu, O'nu cimri olarak isimlendirmemizi gerektirirdi" şeklinde bir iddia ileri sürmesinin yanlış olduğunu bir başka açıdan daha ispat etmeye çalışır. Yani Gazzâlî aslında bunu mevcut dünya gerçekten en mükemmel olduğu için değil, böyle bir düşüncenin zorunlu olarak Allah'ın cömertlik sıfatına halel getirmesi gibi bir sorunu ortaya çıkaracağı için kabul etmez. Fakat İbnü'l-Müneyyir, daha önceki eleştiride de ifade ettiği gibi bu şekildeki bir isimlendirmenin vaz'î olup, aklî olmadığını söylemektedir. Şöyle ki, İbnü'l-Müneyyir, Allah'ın daha mükemmelini yaratmamasının aklî, yani zorunlu olarak O'nun cimrilikle isimlendirilmesini gerektireceği gibi bir iddianın anlamsız olduğunu, eylemlerinde hür olan Allah'ın mükemmeli yaratmasa bile cimri olarak isimlendirilemeyeceğini söylemeye çalışır. ${ }^{43}$

Semhûdî'nin İbnü'l-Müneyyir'in bu eleştirisine karşı yanıtında da ilahî hikmet devreye girer. Ona göre Gazzâlî asla iddiasını mücerret bir isimlendirme üzerine kurmamıştır. Gazzâlî́nin burada dikkat çektiği nokta, hikmetin gerektirmediği şekilde davranmaktan Allah'ın tenzih edilmesinin gerekliliğidir. Nitekim daha mükemmel bir dünya mümkün olsaydı ve Allah bunu yaratmayıp esirgeseydi, hikmetin gerektirdiği bir fiili yapmamış ve bu lütfu esirgemiş olurdu ki, bu da ilâhî hikmet, adalet ve cömertliğe aykırıdır. Çünkü ilâhî hikmetin gereği, adil davranmaktır. Adil davranmakla kastedilen de eşyayı yerli yerine koymaktır. Bunun zıddıysa sefihlik ve ayıptır. Allah, hikmetin kemalinden yoksun bulunan fillerden münezzehtir. ${ }^{44}$

Semhûdî̀ye göre, Allah'ın, hikmeti gereği adil davranmasını bir zorunluluk olarak değil, lütuf ve ihsan olarak anlamamız gerekir. Çünkü Allah kullarını türlü türlü azaplarla, bela ve musibetlerle karşı karşıya bırakmaya kādirdir. Böyle

41 Semhûdî, Îdâh, 7b. Bu konuya dair geniş bilgi için ayrıca bk. Mâtürîdî, Kitâbu't-tevhîd, 251-252; Gazzâlî, elMüstasfâ min 'ilmi'I-usûl (Beyrut: Dâru Ihyâi't-Türâsi'l-Arabi, 1324), 1: 55-57; Gazzâlî, el-Iktisâd fi'l-itikâd, 2. Baskı (Cidde: Dârü'l-Minhâc, 2012), 221-225, 233, 244; Fahreddin Râzî, el-Muhassal, trc. Hüseyin Atay (Ankara: Kültür Bakanlığı Yayınları, 2002), 221-222; Cürcânî, Şerhu'l-Mevâkıf, 3: 312.

42 Semhûdî, Îlâh, 8b.

43 Semhûdî, Îdâh, 8b.

44 Semhûdî, l̂̀âh, 8b. 
yapmış olsaydı bile adaletli davranmış olur ve bu davranış asla çirkin ve zulüm olarak isimlendirilmezdi. Allah kullarını kendisine zorunlu olduğu için değil, lütfu ve kereminden dolayı mükafatlandırır. Zira O'na hiçbir şey zorunlu olmaz, O'nun hakkında asla zulüm tasavvur olunmaz. ${ }^{45}$

Semhûdî burada haklı olarak Gazzâlî́nin Allah'ın kendi mülkünde istediği gibi tasarrufta bulunması şeklindeki bir adalet tanımının, Mûtezile'nin anlayışından farklı olarak Ehl-i Sünnet anlayışı ile tam olarak örtüştüğünü vurgulamaya çalışır. Ne var ki, İbnü'l-Müneyyir söz konusu adalet tanımını, Gazzâlî́yi eleştirmek amacıyla kullanır. O, Gazzâlî́nin Allah daha iyi ve daha mükemmel bir dünya yaratmasaydı adil davranmaz ve zulüm yapmış olurdu ifadesindeki kastının, bu durumda Allah'ın başkasının mülkünde tasarruf etmesi olduğunu iddia eder. ${ }^{46}$

Semhûdî, böyle bir iddianın saçma olduğunu, Allah hakkında başkasının mülkünde tasarrufta bulunma gibi bir durumun düşünülemeyeceğini söyler. Zulüm kavramını eşyayı gerektiği yerine koymamak veya yanlış yerine koymak şeklinde açıklayan Semhûdî, konunun yanlış anlaşıldığını, mülkünde istediği gibi tasarrufta bulunan Allah için en mükemmel olmayanı yaratmanın mümkün ve kudretinin buna yeterli olduğunu, böyle bir yaratmadan dolayı O'nun zalim olarak nitelendirilemeyeceğini söyler. Fakat Allah'ın, en mükemmel şekilde yaratmayı ezelde dilemesi ve hikmetinin böyle bir yaratmayı gerektirmesi, aynı zamanda mülkünde mutlak tasarrufta bulunmak suretiyle adaleti tahsis etmesi, Allah'ı tenzih etmemiz gereken ve O'nun adaletine zıt olan eşyayı kendi yerine koymama fiilini olumsuzlamayı gerektirir. Sonuç olarak Allah hakkında zulüm tasavvur edilemeyeceğine göre $O$, en mükemmel olanı yaratır. ${ }^{47}$

\section{4. İlahî Kudreti Sınırlama}

Allah'ın kudretinin belirli bir sayıyla sınırlandırılması ve kudretin kapsamı altında olan sınırsız mümkünlerin sınırlı yapılması, söz konusu ifadeye yöneltilen en önemli eleştirilerden biridir. ${ }^{48}$ Allah için bu dünyadan daha mükemmelini yaratmanın imkân dâhilinde olduğunu ve mümkün mükemmelliklerin sınırsız olduğunu herkesin kabul ettiğini söyleyen İbnü'l-Müneyyir, O'nun kudretini var olan bir en mükemmelle sınırlamanın imkânsız olduğunu iddia eder. Çünkü böyle bir sınırlama hem mümkünlerin hem de Allah'ın kudreti ve bilgisinin sınırsız olması ile çelişmektedir. İbnü'l-Müneyyir aynı zamanda insanın en mükemmel şekilde yaratılmasını ${ }^{49}$ örnek göstererek buradaki mükemmelliğin var olan yaratıklar arasında geçerli olduğunu, mümkün mükemmelliklerin ise sınırsız olarak kaldığını söyler. Kendisinden daha iyi bir mükemmelin bulunmadığı bir

\footnotetext{
45 Semhûdî, Îdâh, 9b.

46 Semhûdî, Îdâh, 9b.

47 Semhûdî, Îâh, 9b.

48 Semhûdî, Îdâh, 19b.

49 et-Tîn, 95/4.
} 
en mükemmelin var olduğunu kabul ettiğimizi farz edersek bu, sınırsız olanı sınırlamak anlamına gelir. Fakat bu imkânsızdır. Allah'ın kudreti de imkânsız olana taalluk etmemektedir. Bu sebeplerden dolayı Gazzâlî́nin, bu dünyanın imkân dâhilinde var olan en mükemmel dünya olduğunu ifade eden görüşü sınırsız mümkünleri sınırlı yapmakta, aynı zamanda Allah'ın kudretini de bir tek en mükemmelle sınırlamaktadır. Böylece mevcut âlemin imkân dâhilindeki en mükemmel olmasının imkânsızlığı ortaya çıkmaktadır. ${ }^{50}$

Semhûdî bu iddiayı yanıtlamadan önce Allah'ın kudreti dâhilinde olanların ve bilgisinin sınırsız olmasının tartışılmaz olduğunu ve Gazzâlî́nin de bundan farklı bir düşüncede olmadığını ${ }^{51}$ yineler. Ayrıca ona göre bu dünyanın en mükemmel olması, kesin olarak Allah'ın kudreti dâhilinde olanları ve onun bilgisini sınırlandırdığı şeklinde bir sonuca götürmemektedir. Çünkü makdûrâttan var olan ve var olacak her bir şeyin en mükemmel olarak yaratılması, Allah'ın bu mümkünler için en mükemmellik vasfını seçmesinden dolayı olup, Allah'ın kudretinin ve bilgisinin sınırsız olması ile çelişmemektedir. Bu varlıkların hikmetin gerektirmesinden dolayı en mükemmellik sınırında durması ve daha ötesinin olmaması Allah'ın o varlıklardan biri için en mükemmellik vasfını seçerek onu sınırlandırmasından kaynaklanmaktadır. Şöyle ki, Allah'ın bir fert için bu vasfı seçmesi onun bu konuda sonluluğunu gerektirir. Allah için her zaman daha mükemmelin yaratılmasının mümkün olması, O'nun makdûrâttan bir fert için en mükemmellik vasfını seçmesine engel değildir. Nitekim Allah'ın bilgisi ve kudreti dâhilinde olanların sınırsız olması ile kastedilen, her bir ferdin zât ve sıfat olarak sonsuz olması değildir. Allah'ın bazı varlıkları belli bir sayıda ve mükemmellikte yaratarak onları sınırlı yapması O'nun bilgisini ve kudretini sınırlandırmaz. ${ }^{22}$

Semhûdî, hareket, sükûn, birleşme ve ayrılmadan oluşan ${ }^{53}$, cevherlerin kesin olarak bu dört sıfattan biriyle birlikte olduğu ve bunların dışında beşinci bir halin olmadığını her kesin kabul ettiği dört oluşu (ekvân-ı erba'a) örnek göstererek şöyle devam eder: Hiç kimse bu şekildeki bir yaratmanın hem gerçekte var olmasına hem de imkân bakımından durumun sınırlı bulunmasına rağmen Allah'ın bilgisini ve kudretini sınırlandırdığını iddia etmemektedir. Ona göre en mükemmellik vasfı ile varlığın sınırlandırılması da böyledir ve bu durum Allah'ın

50 Semhûdî, Îdâh, 25b.

51 Bk. Gazzâlî, Ihyâ, 1: 95; Gazzâlî, Kavâ'idü'l-akā'id, 2. Baskı thk. Musa Muhammed Ali (Beyrut: Âlemü'l-Kütüb, 1985), 55-56.

52 Semhûdî, Îdâh, 19 b.

53 Filozofların arazları nicelik, nitelik, mekân, zaman, durum, iyelik, görelilik, etkenlik ve edilgenlikten oluşan dokuz kategoriye ayırmalarına karşın kelamcılar arazı canlılara özgü olan ve olmayan şeklinde iki kısma ayııılar. Canlılara ait olan arazlara örnek olarak hayat, ilim, irade, kudret, arzu ve nefret gibi vasıfları gösterebiliriz. Bunların on ile sınırlandırııması kesinlikle yanlıştır. Canlılara özgü olmayanlar ise hareket, sükûn, birleşme ve ayrılmadan ibret olan oluşlar ile beş duyudan biri ile idrak edilen sesler, renkler, kokular, tatlar, sıcaklık ve bunlar gibi olan diğer duyulurlardır. Canlıya özgü olan ve olmayan arazlar altına giren bu kısımlardan her birinin türleri varlık açısından sonludur. (Geniş bilgi için bk. Cürcânî, Şerhu'I-Mevâkıf, 2: 20-38; Abdullatif Harputî, Tenkîhu'I-kelâm fí akāid-i ehli'lislâm, trc. İbrahim Özdemir-Fikret Karaman (Elâzığ: Türkiye Diyanet Vakfı Elâzığ Şubesi Yayınları, 2000), 44-45). 
bilgisi ve kudretini sınırlandırmaz. Çünkü Allah'ın yaratılmış ve yaratılacak olan bir şeydeki en mükemmellik vasfını bilmesi ve bunu tercih etmesi, kudreti dâhilinde olanların sonsuz ve mükemmelliklerin de sınırsız olması ile çelişen bir durum değildir. ${ }^{54}$

Semhûdî, yukarıda anlattıklarına karşı şöyle bir itiraz yapılabileceğini belirtir: "Bir cinste ya hareket ya da sükûn veya ya birleşme ya da ayrılma vardır, başka bir durum söz konusu değildir ve bu da imkân ve gerçekte var olma bakımından o cinsin sonlu ve sınırlı olmasını gerektirir, fakat âlemin en mükemmel olması bunun gibi değildir". Bu itiraza o, mükemmelliklerin imkân olarak sınırsız olduğunu, fakat hikmetin gerektirmesinden dolayı yaratmanın en mükemmellik vasfı ile sınırlandııldığını açıklayarak, semâvâtın belli bir sayıda yaratılmasını da buna örnek göstererek cevap verir. ${ }^{55}$

Fakat İbnü'l-Müneyyir bu örneğin yetersiz olduğunu söyler. Şöyle ki, ona göre Allah'ın mevcut olanın dışında başka semâvâtı ve arzı yaratmayacağını haber vermesi ve bilgisinin de verdiği haber ile doğru orantılı olmasından dolayı, başka semâvât ve arzın yaratılması mümkün değildir. Semhûdî bu iddiaya cevap verirken duyu organlarının gerçekte var olma ve imkân açısından sınırlı olması şeklindeki benzer bir örnekten yola çıkarak İbnü'l-Müneyyir'in verdiği örnekte doğru düşünmediğini kanıtlamaya çalışır. O, elem ve lezzetlerin idrakinin bu beş duyu ile idrak ettiklerimize ilave olup olmadığı konusunda alimler arasında olan ihtilafa ${ }^{56}$ rağmen gerçekte var olan duyularımızın beş ile sınırlı olması konusunda genel ittifakın bulunduğunu söyler. Filozofların kabul ettiği batınî duyular ${ }^{57}$ ise kelamcılar tarafından kabul edilmemektedir. Çünkü kelamcılar, filozofların iç duyularla ilgili delillerinin iddialarını ispat etmekte yetersiz kaldığını söylerler. Vuku bulma açısından mevcut olan bu sınırlamanın çok bariz olduğunu söyleyen Semhûdî, konunun imkân tarafına baktığımız zaman burada başka idraklerin olup

54 Semhûdî, Îlâh, $19 \mathrm{~b}$.

55 Semhûdî, Îlâh, 19b-20a.

56 Eş'arîler'den bir kısmı canlıların kendi nefsinde hissettiği elem ve lezzetlerin idrakinin beş duyu ile hissettiklerimizin dışında kaldığını iddia ederler. Fakat bir kısım Eş'arîler de bu beş zahirî duyu dışında kalan elem ve lezzetin idrak edildiği iki duyunun varlığını ihtilaflı görerek kabul etmemektedirler. (Bk. Bâkıllânî, et-Temhîd, 36-38; Âmidî, Ebkâru'l-efkâr fî usûli'd-dîn, thk. Ahmed Muhammed Mehdi (Kahire: Dârü'l-Kütüb ve'l-Vesâiki'l-Kavmiyye, 2002), 1: 80-81; Cüveynî, el-irşâd ilâ kavâtii'I-edilleti fî usûli'I-i'tikād, thk. Muhammed Yusuf Musa (Kahire: Mektebetü'lHanci, 1950), 173-174; Abdulkāhir Bağdâdî, Kitâbu usûli'd-dîn, trc. Ömer Aydın (İstanbul: İşaret Yayınları, 2016), 35-36.)

57 Kelamcılardan farklı olarak filozoflar sem' (işitme duyusu), basar (görme duyusu), şemm (koklama duyusu), zevk (tatma duyusu) ve lems (dokunma duyusu) şeklinde var olan beş zahirî duyuların dışında el-hissü'l-müşterek (ortak duyu gücü), el-kuvvatü'l-musavvire (tasavvur gücü), hayvanî nefis söz konusu olduğunda el kuvvetü'lmütehayyile veya insanî nefis söz konusu olduğunda el-kuvvetü'l-mütefekkire (hayal gücü), el-kuvvetü'lvehmiyye (vehim gücü), el-kuvvetü'l-hafıza (hatırlama gücü) olmak üzere beş iç duyunun varlığını da kabul etmektedirler. (Bk. İbn Sînâ, en-Necât fi'l-hikmeti'l-mantıkiyye ve't-tabiiyye ve'l-ilâhiyye, 2. Baskı thk. Muhyiddin Sabri el-Kürdi (Kahire: Matbaatü's-Saade, 1938), 158-163). 
olmadığı meselesinin ihtilaflı olduğunu ifade etmektedir. Düşünür, Eş'arîler'in vuku açısından mevcut duyuların sınırlı olmasını kabul etmelerine rağmen imkân olarak bunları herhangi bir sayıyla sınırlandırmadıklarını söyler. ${ }^{58}$

Bu ve benzeri örneklerde gördüğümüz gibi makdûrâtın sonsuz olması ile yaratılanların mükemmelliğin son sınırında bulunması birbiriyle çelişmemektedir ve burada İbnü'l-Müneyyir'in iddia ettiği gibi Allah'ın kudretini ve bilgisini sınırlandıracak herhangi bir durum söz konusu değildir.

İbnü'l-Müneyyir Allah'ın kudretinin sınırlandırılmasına dair eleştirisine devam ederek Gazzâlî́nin bu görüşü benimsemekle varlığa, en mükemmellik sınırında bulunması durumunun ötesinde herhangi bir şey eklenmesini imkânsız kıldığını söyler. Bu da açıkça Allah'ın kudretini sonlu bir sayı ve aşılamayan bir sınırla kısıtlamak anlamına gelir. ${ }^{59}$ illâhî kudretin sınırsız olduğunu söyleyen Semhûdî'nin bu eleştiriye cevap niteliğinde Mevâkıf tan yaptığı alıntı çok isabetlidir:

"Allah'ın kudreti ister zât, isterse de taalluk ettiği şeylerle ilişkisi bakımından sonlu olmakla nitelenemez. Zat bakımından sonsuz olması, sonluluğun niceliğin özelliklerinden olmasından dolayıdır. Çünkü kudret için nicelik değil nitelik söz konusudur. Taalluk ettiği şeylerle ilişkisi bakımından sonsuz olması ise kudretin, taallukunun ötesinde başkasına taalluk etmesinin imkânsız olduğu bir sınırda durmayacağı anlamına gelir. Eğer kudretin bilfiil taalluk ettiği nesnelerin hepsi sonluysa, her zaman bilkuvve sonsuz olmasına rağmen onun kudretin nesneleri ile olan ilişkisi de nesnelerin sonlu olmasından dolayı bilfiil sonlu olmaktadır." ${ }^{\prime 60}$

Semhûdî, bu referansın cevap olarak yeterli olacağını düşünerek daha önce de ifade ettiğimiz gibi Gazzâlî́nin ilâhî kudreti herhangi bir sayı veya sınırla kısıtlamadığını, bilakis onun nesnelerinin ve ilâhî bilginin sınırsız olduğunu ifade ettiğini ${ }^{61}$ söyler, ayrıca İbnü'l-Müneyyir'in nasıl böyle bir düşünce içerisinde olduğuna hayret eder. Durumun burada farklı olduğunu söyleyen Semhûdî, Allah'ın sayısız en mükemmellikler yaratabileceğini ve buna kādir olduğunu, fakat bu durumun O'nun bu mümkünler içerisinden hikmetin ve ilâhî iradenin gerektirdiği bir en mükemmeli seçmesine engel olmadığını iddia etmektedir. Ayrıca burada mevcut varlığa herhangi bir şey eklemenin imkânsız olması, kendi özünde imkânsızdır anlamına gelmemektedir. Bilakis daha önce de defalarca belirtildiği gibi var olan en mükemmelden başkasının yaratılmasının imkânsız olması, Allah'ın hikmeti, iradesi ve kudretinin sınırsız mümkünler arasından en tam, en uygun ve en mükemmel olanı seçmesinden kaynaklanmaktadır. ${ }^{62}$

58 Semhûdî, Îdâh, 20a.

59 Semhûdî, Îdâh, 22a.

60 Adududdîn Abdurrahman b. Ahmed el-Î̂î, el-Mevâkıf fî ilmi'l-kelâm (Kahire: Mektebetü'l-Mütenebbi, ts.), 282; Cürcânî, Şerhu'I-Mevâkıf, 3: 96-97.

61 Gazzâlî, Ihyâ, 4: 346.

62 Semhûdî, Îdâh, $22 \mathrm{~b}$. 
"Mümkün, var olması ve olmaması eşit olandır" tanımını hatırlatarak savunmasına devam eden Semhûdî, İbnü'l-Müneyyir'in "mükemmellikler imkân olarak sınırsızsa kendisinden daha mükemmelinin bulunmadığı bir en mükemmelden bahsedemeyiz" şeklindeki itirazına cevap verirken şunları söyler: Mevcut mükemmelden daha mükemmelinin olması konusundaki mücerret imkân, Allah'ın kudreti ile bu en mükemmel arasındaki ilişkinin imkânsızlığını gerektirmez. Şöyle ki, biz Allah'ın, kudretinin taalluk ettiği şeyden daha mükemmel olan mümkünü yaratmayı istemediğini düşünürsek, o zaman Allah'ın kudretinin yaratılmasına taalluk ettiği varlık, hatta ondan daha mükemmeli imkân dâhilindeyse bile, var olma açısından en mükemmel olan durumuna gelir. Ve düşünüre göre bu durumda daha mükemmel olan her zaman mümkün görülse bile, Allah'ın kudretinin var olma açısından daha mükemmel olmasını istemediği mükemmellik derecelerinden biri ile ilintili olması çelişkili ve imkânsız değildir. ${ }^{63}$

Semhûdî'nin burada anlatmak istediği, Allah'ın irade ve hikmetinin sınırsız mükemmellikler arasından bir en mükemmeli tercih etmesinin, imkân olarak bundan daha mükemmelinin mümkün olmasına rağmen, tercih edilenin o an için en mükemmel olduğunu gösteriyor olmasıdır. Allah'ın diğer en mükemmellerin yaratılmasını dilememesi de yaratılma için tercih edilenin mükemmellik olarak en üstün olduğunu ispatlar. Ayrıca Allah'ın hikmeti iradesi ve kudreti sınırsız olanı sınırlı yapabilir. Nitekim Semhûdî, yukarıda İbnü'l-Müneyyir'in Allah'ın kudretinin bir en mükemmelle sınırlanmasının muhal olduğu ve kudretin imkânsız olanla, yani var olan en mükemmelle hiçbir ilişkisinin olmadığı şeklindeki iddiasını, ümmetin Hz. Muhammed'i gelmiş geçmiş en üstün ve en faziletli insan olarak kabul etmesinin çürüttüğünü söyler. İşbu sebepten, der Semhûdî, Allah'ın makdûrâtı imkân açısından sınırsız olsa da O'nun Hz. Muhammed'i en mükemmel şekilde yaratması, kudretin bir en mükemmelle ilişkisinin muhal olmadığını ve hikmetin, sınırsız olanı bir en mükemmelle sınırlayabileceğini kanıtlar niteliktedir. Sonuç olarak kendisinden daha mükemmeli bulunmayan bir en mükemmelin var olması imkânsız değildir ve Allah imkân olarak sınırsız olanı sınırlı yapmaya kādirdir. Ve işte bu durum O'nun âciz olmasını değil, bilakis kudretinin ve hikmetinin gücünü gösterir. ${ }^{64}$

İbnü'l-Müneyyir'i Allah'ın kudretinin sınırlandırılmasıyla ilgili olarak rahatsız eden diğer bir konu da Gazzâlî́nin âcizlik ile kudretin yokluğunu kastetmiş olmasıdır. Şöyle ki, o Gazzâlî́nin "eğer var olandan daha mükemmel bir dünya mevcut olsaydı ve Allah bunu yaratmaya kādir olmasaydı bu âcizlik olurdu" demesinin anlamsız olduğunu, âcizliğin kudretin yokluğu anlamına gelmediğini ve bunun örfi bir kullanım olduğunu ifade eder. Bu tarz kullanım yanlıştır diyen İbnü'l-Müneyyir, bir taşın da kudretinin olmadığını, fakat onu âciz olarak

63 Semhûdî, Îdâh, 26b-27a.

64 Semhûdî, Îdâh, 27a.-27b. 
isimlendiremeyeceğimizi söyler. Ezeli kudret imkânsız olana taalluk etmediği için burada herhangi bir acziyetten bahsedemeyiz diyen İbnü'l-Müneyyir, Eş'arî'nin de âcizliği kudretin yokluğu değil, onun zıddı olarak tanımladığını ${ }^{65}$ belirtir. Ayrıca sadece hâdis olana taalluk eden âcizlik, hâdis kudretin var olduğu zaman yapılacak olana taalluk etmesi gibi, var olduğu zaman yapılamayacak olana da taalluk etmesidir. Bu durumun, İbnü'l-Müneyyir'e göre ezeli kudretle herhangi bir ilişkisi olamaz. Şöyle ki, o, eğer Allah var olandan daha iyi bir dünyayı yaratmadıysa, bu O'nun âciz olmasından dolayı değil, böyle bir şeyin muhal olması ve ezelî kudretin imkânsızla herhangi bir ilişkisinin olmamasından kaynaklandığını belirterek, Gazzâlî́nin, kudretin herhangi bir şeye taalluk etmemesini âcizlik olarak tanımlamasının yanlış olduğunu iddia etmektedir. ${ }^{66}$

Semhûdî, İbnü'l-Müneyyir'in bu eleştirilerine karşı sert çıkarak onu Gazzâlî'nin gerçek amacını tahrif etmekle suçlar. Çünkü Gazzâlî bu görüşünü, Allah'ın en mükemmel olanı yaratmasının hikmetin gerektirdiği bir şey olması üzerine inşa eder. Burada anlatılmak istenen şudur: eğer biz mevcut dünyanın mükemmelliğinin üzerinde bir mükemmelin mümkün olduğunu ve Allah'ın hikmetin gerektirdiği bu en mükemmeli yaratmaya gücünün yetmediğini farz etseydik, bu durumda Allah'ın bu mümkünü yaratma konusunda kudretinin yetersiz olması, uluhiyet ile bağdaşmayan âcizlik olurdu. Tüm mümkünleri kapsayan ilâhî kudretin bazı mümkünler konusunda yetersiz kalması eksiklik olur. Gazzâlî́nin âcizlikle kastettiği şey de tam olarak budur. Eş'arî'nin bu eksikliği âcizlik olarak adlandırmaması durumun böyle olmadığını göstermez. Aynı zamanda İbnü'l-Müneyyir'in Gazzâlî́ye atfettiği kudretin herhangi bir şeye taalluk etmemesini âcizlik olarak adlandırdığı iddiası da sırf kuru iftira ve onu küçük düşürmekten başka bir şey değildir. Zira burada kast olunan kudretin yokluğu değil, Allah'ın mümkün olan bir en mükemmeli yaratmaya muktedir olmamasıdır. Eğer mevcut alemden daha mükemmel olanı mümkünse ve Allah'ın bunu yaratmaya gücü yetmiyorsa, bu durumda O'na âcizlik atfedilebilir. Netice-i kelâm şudur ki, mevcut âlem imkân dâhilinde en mükemmel olanıdır. ${ }^{67}$

Buraya kadar dile getirilen fikirleri özetle şu şekilde ifade etmek mümkündür: Bu âlem, Semhûdî'ye göre Allah'ın bilgisi ve iradesinin takdiri ile mümkün âlemler içerisinden hür bir irade ile seçilmiş, içerisinde belli bir amaca yönelik kötülükler ve iyilikleri aynı anda barındıran, bilgi ve hür iradenin ezelde takdirinden dolayı hikmet gereği yaratılması zorunlu hâle gelen en mükemmel âlemdir. Allah'ın kudreti dahilinde olanlardan yaratılan ve yaratılacak olan her bir şeyin en mükemmel olması, Allah'ın bunlar için en mükemmellik vasfını seçmesinden kaynaklanmakta ve bu duruma bağlı olarak bu dünyanın en mükemmel olması,

65 Eş'arî, Kitâbu'l-Luma' fî redd alâ ehli'z-zeyğ va'I-bida' (Kahire: el-Hey'etü'l-Âmme li'ş-Şuûni'l-Metâbi'I-Emîriyye, 1975), 39-40.

66 Semhûdî, Îdâh, 28a.

67 Semhûdî, Îdâh, 28a. 
O'nun kudretini ve bilgisini sınırlandırmamakta, bilakis, âlemin en mükemmel olması ve ötesinin imkânsız olması, hikmeti iradesi ve kudretinin sınırsız olanı sınırlı yapabilen Allah'ın hikmetinin gerektirdiği bir sınırda onu durdurmasından kaynaklanmaktadır.

\section{SONUÇ}

Semhûdî́nin, Îdâhu'l-beyân'ında âlemin mükemmelliğine dair Gazzâlî́nin fikirlerini savunurken kullandığı yöntemlerin ve bu doğrultuda sergilediği argümanların özgün olduğunu söylemek mümkündür. Eleştiri ve baskılar açısından Gazzâlî'den daha avantajlı bir durumda olan Semhûdî, bu konuda görüş belirtirken klasik Eş’arî düşünce geleneğinin sınırları içerisinde kalmak için bir gayret sarf etmez. Onun bu konudaki rahatlığının, hadis ve fıkıh alanında da eserler yazmasına rağmen çalışmalarında daha çok tarih üzerine yoğunlaşan bir âlim olmasından, aynı zamanda Gazzâlî gibi bir Eş'arî düşünce okulunun önemli bir temsilcisi olmamasından kaynaklanmış olabileceğini düşünmek yanlış olmasa gerek. Şöyle ki, yukarıda gördüğümüz kadarıyla Semhûdî, Gazzâlî'nin bu konuda görüş belirtirken ima ettiği fakat açıkça ifade etmediği birçok konuda detaylara inerek üstü kapalı kalan yerleri açıklığa kavuşturmuş ve Gazzâlî'nin temellerini attığı dogmatik Eş'arî düşüncesini yumuşatma çabasını daha da ileri taşımıştır. Nitekim Semhûdî'nin, hemen hemen tüm eleştirilere karşı geliştirdiği savunmalarında her zaman destek aldığı ilahi hikmet ve adalet gibi kavramları Mâtürîdiyye'nin kabul ettiği şekliyle ve zaman zaman da filozofların ve Mûtezile'nin görüşlerini Ehl-i Sünnet düşüncesine uygunlaştırarak kullanması bu konuda belli bir mezhebe bağlı kalmadığını gösterir niteliktedir.

Durumu bir az daha ileri götürerek Semhûdî'nin bu çabasının, olaylara sadece tek bir îtikādî mezhebin penceresinden değil de Eş'arîyye, Mâtürîdîyye ve bazı konularda da Mûtezile gibi ekolleri tek çatı altında birleştiren yeni bir Ehl-Sünnet bakış açısıyla bakma olduğunu söylemek yanlış bir iddia olmazdı. Ne var ki, Semhûdî́nin sadece burada değil, genel olarak böyle bir yöntemi benimsediği şeklinde bir fikir ileri sürmek için maalesef elimizde yeteri kadar bilgi ve işbu iddiayı ispat etmemiz adına kelâmî konuları tartışan başka bir eseri bulunmamaktadır. Bu sebepten de mevcut durumu göz önünde bulundurarak bu konuda kesin olarak bir kanıya varmanın şimdilik anlamsız olduğu söylenebilir.

Ve nihayet bu çalışma sayesinde farkına varılan hakikat şudur ki, Semhûdî'nin, âlemin mükemmelliği meselesine dair kurduğu argümanlarını kıymetli bulduğu Gazzâlî'nin fikirlerini özellikle İbnü'l-Müneyyir'in eleştirilerine karşı savunurken sergilediği tutarlı akıl yürütmelerinin sağlam fikirler hâlinde dile gelmesi özellikle takdire değer bir niteliktir. Ve nihâyet, Semhûdî'nin söz konusu fikirler ve eleştiriler düzlemini inşa ederken tek bir mezhebe bağlı kalmayarak tüm mezhepleri kuşatacak bir metodolojiye varma çabası, kelâm tarihi bakımından önemli bir niyet ve hatırlanmaya değer bir çaba olması hasebiyle övgüyü hak etmektedir. 


\section{KAYNAKÇA}

Âmidî, Seyfuddin. Gāyetü'I-merâm fî ilmi'l-kelâm. Thk. Hasan Mahmûd Abdüllatif. Kahire: Vizaretü'l-Evkaf, 1971.

Âmidî. Ebkâru'I-efkâr fî usûli'd-dîn. 5 Cilt. Thk. Ahmed Muhammed Mehdi. Kahire: Dârü'lKütüb ve'I-Vesâiki'l-Kavmiyye, 2002.

Bağdâdî, Abdulkāhir. Kitâbu usûli'd-dîn. Trc. Ömer Aydın. İstanbul: İşaret Yayınları, 2016.

Bâkıllânî, Ebû Bekr Muhammed b. Tayyib. et-Temhîd fír-red 'ale'l-Mülhideti'I-Mu'attıla va'rRâfidati va'I-Hâvâric va'l-Mûtezile. Kahire: Dârü'I-Fikri'l-Arabî, 1947.

Bedevî, Abdurrahman. Muellefâtü'I-Gazzâlî. 2. Baskı. Kuveyt: Vekaletü'I-Matbuat, 1977.

Beyzâvî, Ebû Saîd Abdullah b. Ömer b. Muhammed. Tavâli'u'l-envâr min metâli'i'l-enzâr. Trc. İlyas Çelebi-Mahmut Çınar. İstanbul: Türkiye Yazma Eserler Kurumu Başkanlığı Yayınları, 2014.

Cürcânî. Şerhu'I-Mevâkıf. 3 Cilt. Trc. Ömer Türker İstanbul: Türkiye Yazma Eserler Kurumu Başkanlığı, 2015.

Cüveynî. el-Irrşâd ilâ kavâtili'-edilleti fî usûli'l-i'tikād. Thk. Muhammed Yusuf Musa. Kahire: Mektebetü'l-Hanci, 1950.

Eflatun. Politeia. Trc. Sabahattin Eyuboğlu-M. Ali Cimcoz. İstanbul: Türkiye İş Bankası Kültür Yayınları, 1999.

Eflatun. Theaitetos. Trc. Macit Gökberk. Ankara: Millî Eğitim Bakanlığı, 1945.

Eflatun. Timaios. Trc. Erol Güney-Lütfi Ay. İstanbul: Sosyal Yayınları, 2001.

Eş'arî. Kitâbu'I-Luma' fî redd alâ ehli'z-zeyğ va'I-bida'. Kahire: el-Hey'etü'l-Âmme li'ş-Şuûni'lMetâbi'l-Emîriyye, 1975.

Eş'arî. Makālâtü'l-islâmiyyîn ve ihtilâfu'l-musallîn. Trc. Mehmet Dalkılıç-Ömer Aydın. İstanbul: Kabalcı Yayınevi, 2005.

Eşmûnî, Ebu'l-Hasan Nûreddin Ali b. Muhammed b. İsa. Teşyîdü'l-erkân fî leyse fíl-imkân ebde'u mimmâ kân. Şehit Ali Paşa, nr. 2707: 79b-90a. Süleymaniye Kütüphanesi.

Gazzâlî, Ebû Hâmid. Makāsidü'l-felâsife. Trc. Cemaleddin Erdemci. Ankara: Vadi Yayınları, 2001.

Gazzâlî. Cevâhiru'I-Kur'ân ve düreruhu. Thk. Hatice Muhammed Kâmil. Kahire: Darü'I-Kütüb ve'I-Vesaiki'l-Kavmiyye, 2011.

Gazzâlî. el-iktisâd fi'l-itikâd. 2. Baskı. Cidde: Dârü'l-Minhâc, 2012.

Gazzâlî. el-imlâ fî işkâlâti'l-ihyâ. (İhyâ'nın zeylinde). 4. Baskı. 6 Cilt. Beyrut: Dârü'l-Hayr, 1997.

Gazzâlî. el-Maksadü'l-esnâ fi şerhi esmâillahi'I-hüsnâ. Beyrut: Dârü'l-Kütübi'l-IImiyye, ts.

Gazzâlî. el-Munkız mine'd-dalâl. Trc. Abdurrezzak Tek. Bursa: Emin Yayınları, 2013.

Gazzâlî. el-Müstasfâ min 'ilmi'I-usûl. 2 Cilt. Beyrut: Dâru İhyâi't-Türâsi'l-Arabi, 1324.

Gazzâlî. Ihyố'u 'ulûmi'd-dîn. 4 Cilt. Kahire: Mustafa el-Bâbî el-Halebî, 1939.

Gazzâlî. Kavâ'idü'l-akā'id. 2. Baskı. Thk. Musa Muhammed Ali. Beyrut: Âlemü'l-Kütüb, 1985.

Gazzâlî. Kitâbu'I-Erbaîn fî usûli'd-dîn. Kahire: Matbaatu Kürdistani'I-IImiyye, 1328. 
Harputî, Abdullatif. Tenkîhu'l-kelâm fî akäid-i ehli'l-islâm. Trc. İbrahim Özdemir-Fikret Karaman. Elâzığ: Türkiye Diyanet Vakfı Elâzığ Şubesi Yayınları, 2000.

Hick, John. Evil and the God of Love. London: Macmillan, 1993.

Hume, David. Dialogues Concerning Natural Religion. Trc. Mete Tunçay. Ankara: Kültür Bakanlığı, 1979.

İbn Sînâ.en-Necât fi'l-hikmeti'l-mantıkiyye ve't-tabiiyye ve'l-ilâhiyye. 2. Baskı. Thk. Muhyiddin Sabri el-Kürdi. Kahire: Matbaatü's-Saade, 1938.

İbnu'l-Hatîb, Lisânuddîn. el-ihâtâ fí ahbâri Gırnâta. 2. Baskı. 4 Cilt. Thk. Muhammed Abdullah İnan. Kahire: Mektebetü'l-Hanci, 1975.

İbnü'l-Mübarek, Ahmed. el-ibrîz min kelâmi Seyyidî Abdülaziz ed-Debbağ. B.y: Dârü'l-Fikr, ts.

Îcî, Adududdîn Abdurrahman b. Ahmed. el-Mevâkıf fî ilmi'l-kelâm. Kahire: Mektebetü'lMütenebbi, ts.

İskenderî, İbn Atâullah. et-Tenvîr fî iskâti't-tedbîr. Beyrut: Dârü'l-Kütübi'I-IIlmiyye, 1998.

Kadı Abdulcebbâr. el-Muğnî fî ebvâbi't-tevhîd ve'l-adl. 13 Cilt. Thk. Mahmûd Muhammed Hudayrî. Kahire: ed-Darü'l-Mısriyye, 1963.

Kaya, Eyyüp Said. "Mâzerî". Türkiye Diyanet Vakfı İslâm Ansiklopedisi. 28: 193-195. Ankara: TDV Yayınları, 2003.

Kılıç, Muharrem. "Turtûşî". Türkiye Diyanet Vakfı İslâm Ansiklopedisi. 41: 430-431. İstanbul: TDV Yayınları, 2012.

Mâtürîdî. Kitâbu't-tevhîd. Trc. Bekir Topaloğlu. Ankara: Türkiye Diyanet Vakfı İslam Araştırmaları Merkezi (ISAM) Yayınları, 2002.

Nesefî. Kitâbu't-temhîd li kavâidi't-tevhîd. Trc. Hülya Alper. İstanbul: İz Yayıncılık, 2007.

Nesefî. Tebsıratü'l-edille. 2. Baskı. 2 Cilt. Thk. Hüseyin Atay. Ankara: Diyanet İşleri Başkanlığı Yayınları, 2004.

Ormsby, Eric Linn. Theodicy in Islamic Thought; The Dispute Over al-Ghazali's Best of All Possible Worlds. Trc. Metin Özdemir. Ankara: Kitabiyat Yayınları, 2001.

Pezdevî, Ebü'l-Yüsr Muhammed. Usûlu'd-dîn. Trc. Şerafeddin Gölcük. İstanbul: Kayıhan Yayınevi, 1980.

Râzî, Fahreddin. el-Muhassal. Trc. Hüseyin Atay. Ankara: Kültür Bakanlığı Yayınları, 2002.

Sâbûnî.el-Bidâye fîusûli'd-dîn. 10. Baskı. Trc. Bekir Topaloğlu. İstanbul: Marmara Üniversitesi İlahiyat Fakültesi Vakfı Yayınları, 2012.

Semhûdî, Nûreddin. Îdâhu'I-beyân limâ erâdehu'l-Hucce min leyse fi'l-imkân ebde'u mimmâ kân. Ayasofya, nr. 2187: 15b-39b. Süleymaniye Kütüphanesi.

Seyyid Bey. Usûl-i Fıkıh. 2 Cilt. İstanbul: Karabet Matbaası, 1338.

Sübkî, Tâceddîn Ebî Nasr Abdulvehhâb b. Ali b. Abdilkâfi. Tabakātü'ş-Şâfi'iyyeti'l-kübrâ. 10

Cilt. Thk. Mahmûd Muhammed Tanâhî-Abdülfettah Muhammed el-Hulv. B.y: İsa elBâbî el-Halebî, 1968.

Süyûtî, Celâleddîn. Teşyîdü'l-erkân fî leyse fí'l-imkân ebde'u mimmâ kân. Şehit Ali Paşa, nr. 2707: 69b-78b. Süleymaniye Kütüphanesi. 
Süyûtî. Kitâbu Buğyetü'I-vu'ât fî tabakâti'I-luğaviyyîn ve'n-nuhât. Kahire: Matbaatü's-Saade, 1326.

Şehristânî. el-Milel va'n-nihal. Trc. Mustafa Öz. İstanbul: Litera Yayıncılık, 2008.

Şehristânî. Nihêyetü'l-ikdâm fî ilmi'l-kelâm. Thk. Alfred Guillaume. London: Oxford University, 1934.

Şeyhzâde, Abdurrahîm b. Ali. Nazmu'l-ferâid va cem'u'l-fevâid. Kahire: Matbaatü'l-Edebiyye, h. 1317.

Voltaire. Dictionnaire Philosophique. 4. Baskı. 4 Cilt. Trc. Lutfi Ay. İstanbul: İnkılap ve Aka Kitabevleri, 1973.

Weber, Alfred. Felsefe Tarihi. 3. Baskı. Trc. H. Vehbi Eralp. İstanbul: Remzi Kitabevi, 1964.

Zebîdî, Ebü'l-Feyz Muhammed b. Muhammed el-Hüseynî. İthâfü's-sâdeti'l-muttakîn bişerhi esrar-i Ihya-i ulûmi'd-dîn. 10 Cilt. Kahire: Matbaatü'I-Meymeniyye, 1311.

Zehebî, Şemsuddîn Ebî Abdullah Muhammed b. Ahmed b. Osman. Târîhu'l-Islâm va vafeyâtü'l-meşâhîr va'l-a'lâm. 17 Cilt. Thk. Beşşar Avvad Ma'ruf. Beyrut: Dârü'l-Garbi'lİslamî, 2003. 